\title{
A CIDADE COMO HISTÓRIA
}

\author{
The city as history \\ Marisa Varanda Teixeira Carpintéro* \\ Josianne Francia Cerasoli**
}

\begin{abstract}
RESUMO
A vasta produção acadêmica sobre cidades é proporcional ao interesse de diversas áreas do conhecimento a respeito do tema. Na impossibilidade de um balanço de toda a produção, mesmo que circunscrita somente às áreas selecionadas para esta apresentação - arquitetura e história -, optamos pelos seguintes temas: no campo dos arquitetos, escolhemos os que recorreram à historiografia como patamar de análise de planos e intervenções urbanísticas, procedimentos de higienização de áreas da cidade e processos envolvendo questões de moradia para população de baixa renda. Discutimos as concepções de história que atravessam esses estudos, no sentido de fortalecer o diálogo valioso e essencial entre a história e a arquitetura, além de problematizar os aspectos mais significativos dessa aproximação. No campo dos historiadores, apresentamos um mapeamento das pesquisas sobre questões urbanas e analisamos criticamente os paradigmas e aportes explicativos do campo da história empregados nos estudos sobre cidades. A percepção da presença oblíqua da cidade como temática na historiografia brasileira justifica e orienta uma avaliação crítica das opções dos historiadores, bem como a discussão de alguns dilemas e possibilidades de abordagem.
\end{abstract}

Palavras-chave: cidade (história); urbanismo (história); São Paulocidade (história).

\footnotetext{
ABSTRACT

The vast academic production about cities is proportional to the interest of numerous branches of knowledge on the subject. Since it was impossible to evaluate the entire production, even if limited only to areas selected for this presentation - architecture and history -, we

"Doutora em História, pós-doutoranda em História na Unicamp. E-mail: mvcarpin@uol.com.br.

** Doutora em História, professora (adjunto 2) do Instituto de História da Universidade Federal de Uberlândia. E-mail: josiannefc@gmail.com.
} 
chose the following topics: at the architects field, we chose those that refer to the historiography as subject of analysis of plans and cities operations planning, procedures for cleaning of areas of the city and the processes involving issues of housing for low-income population. We discussed the concepts of history running through these studies, to strengthen the valuable and essential dialogue between history and architecture, and to inquire the most significant features of this approach. In the field of historians, we present a survey of research on urban issues and critically analyze the contributions and explanatory paradigms of the field of history employed in studies of cities. The perception of an oblique presence of the city as a theme for the Brazilian historiography justifies and directs a critical assessment of the options from historians, as well as the discussion of dilemmas and possibilities of approach.

Key-words: city (history); urban (history); São Paulo-city (history).

Nos últimos anos, a produção acadêmica sobre temas relacionados à cidade aumentou de modo significativo, o que faz da tarefa de apresentá-la e analisá-la criticamente uma ousadia sem limites. Antes reduto de alguns arquitetos, geógrafos e sociólogos, recebe há já alguns anos a atenção dos historiadores que, com seus colegas das outras áreas, compõem um amplo painel de recortes temáticos e de aproximações teóricas. Nesse painel, a variedade de temas e o modo como são problematizados se subordinam à formação disciplinar dos autores, compondo opções teóricas fundamentadas em campos conceituais e/ou modelos explicativos específicos de suas áreas. $\mathrm{Na}$ impossibilidade de dar conta de um quadro tão amplo de livros, artigos e trabalhos acadêmicos (mestrados e doutorados), decidimos circunscrever essa apresentação a uma parcela da produção de arquitetos e de historiadores. Entre as razões da escolha está nossa avaliação da existência de um importante diálogo entre as duas áreas em torno dessa temática. Está também o entendimento de que as aproximações progressivas dessas duas áreas conhecimento se relacionam historicamente com a própria formação dos campos conceituais mobilizados para o estudo e a intervenção nas cidades $^{1}$.

1 Sobre as intersecções entre os dois campos de saber analisadas a partir de uma reflexão sobre o urbanismo acompanhamos o interessante artigo de Novik. Merece destaque o modo como aborda a importância do urbanismo na instauração de novas representações sobre a cidade ao transcender as fronteiras de um campo disciplinar. NOVIK, Alicia. El urbanismo em las historias de la ciudad. Registros. Revista de Investigación del Centro de Estudios Históricos Arquitectónico-Urbanos. Mar Del Plata: FAUUNMDP, n.1, p.6-26, 2003. 
Para os percursos deste artigo, a opção no campo dos arquitetos recaiu sobre aqueles que recorreram à historiografia como patamar de análise de planos e intervenções urbanísticas, procedimentos de higienização de áreas da cidade e processos envolvendo questões de moradia para população de baixa renda. Já no campo dos historiadores, o caminho escolhido foi o de apresentar um mapeamento da situação das pesquisas sobre questões urbanas e analisar criticamente os paradigmas e aportes explicativos do campo da história empregados nos estudos sobre cidades. Nas duas escolhas não se trata de levantamentos ou balanços bibliográficos exaustivos e sim da eleição de algumas discussões consideradas por nós amplamente relevantes para o entendimento da cidade - da cidade como história. Os dois campos são apresentados em sequência em função de decisões formais, mas se verá que muitas questões propostas em cada um dialogam e exigem intersecções e aproximações entre ambas, tal como as áreas aqui escolhidas².

\section{O espaço da história nos estudos sobre a cidade: um percurso pela produção dos arquitetos}

Durante alguns anos, constatamos na leitura de uma série de livros e artigos escritos por arquitetos, sociólogos, geógrafos e economistas o recurso a interpretações históricas como base para problematizar as cidades modernas. Foi interessante constatar a reduzida presença de historiadores discutindo temas relativos à cidade e à habitação, frente à gama de estudos produzidos por outras disciplinas. O percurso dessas reflexões recorta uma pequena parcela da produção sobre a temática da cidade e da moradia para a população de baixa renda na cidade de São Paulo, resgatando os estudos realizados pelos arquitetos durante os anos de 1960 a 1990.

2 Desde as primeiras discussões sobre os percursos escolhidos para esta apresentação até as sucessivas leituras dos esboços parciais pudemos contar com o imprescindível apoio e as preciosas sugestões de Stella Bresciani, a quem somos muito agradecidas. Os eventuais equívocos e imprecisões, porém, são de inteira responsabilidade das autoras. 
Sentimos aqui a necessidade de compartilhar com outros historiadores as discussões concernentes às concepções de história que atravessam esses estudos, no sentido de fortalecer o diálogo valioso e essencial entre a história e a arquitetura. Por outro lado, salientamos a responsabilidade da historiografia brasileira, que nos últimos anos tratou a cidade, predominantemente, apenas como palco das transformações políticas e econômicas, ou então, como cenário para os grandes acontecimentos sociais.

É extensa a lista da produção na área de arquitetura, o que nos obrigou a optar por analisar algumas obras. Nossa escolha para essa avaliação bibliográfica recaiu em professores e ex-alunos de arquitetura que desenvolveram seus estudos nos programas de pós-graduação da Universidade de São Paulo (FAU/USP) e na Escola de Engenharia de São Carlos (EESC/USP). Seus trabalhos muito contribuíram para os estudos sobre a história da arquitetura, do urbanismo e da habitação no Brasil e constituem referências constantes em artigos, livros e teses. Entre os selecionados, figuram os arquitetos Carlos A. C. Lemos, Nestor Goulart Reis Filho e Benedito Toledo Lima como representantes da produção das décadas de 1960 e 70, além de estudos mais recentes dos arquitetos Carlos Monteiro de Andrade, Raquel Rolnik, Nabil Bonduki, Hugo Segawa, Cândido Malta Campos, Regina Meyer, Sylvia Ficher e Sarah Feldman, além da filósofa Maria Cecília Loschiavo dos Santos e da socióloga Maria Ruth Sampaio.

A seleção dos respectivos autores se justifica pelos seguintes motivos: a possibilidade de com essa pequena amostragem mostrar as diversas concepções de história que definem o eixo central do debate nos estudos sobre a cidade e a habitação. Salientamos também a impossibilidade de estender a análise para muitos dos trabalhos escritos por esses e outros autores sobre a cidade de São Paulo ou tratando de outras cidades brasileiras, pois nos arriscaríamos, dada a enormidade da tarefa, a fazer desse texto uma resenha bibliográfica ou um mero sistema classificatório ${ }^{3}$. Entretanto,

3 Cabe aqui enfatizar outras obras importantes dos autores mencionados, LEMOS, Carlos. A. C. Cozinhas, etc. São Paulo: Editora Perspectiva, 1978; LEMOS, Carlos. A. C. Casas paulistas: História das moradias anteriores ao ecletismo trazido do café. São Paulo: EDUSP, 1990; ROLNIK, Raquel. A cidade e a lei - legislação, política urbana e territórios na cidade de São Paulo. Col. Cidade Aberta. São Paulo: Studio Nobel-Fapesp, 1997; SEGAWA, Hugo. Prelúdio da metrópole: Arquitetura e Urbanismo em São Paulo na passagem do século XIX-XX. São Paulo: Ateliê Editorial, 2000; REIS Filho, Nestor Goulart. Quadro da Arquitetura no Brasil. São Paulo: Perspectiva, 1970; TOLEDO, Benedito Lima de. Prestes Maia e as origens do urbanismo moderno em São Paulo. São Paulo: Empresa das Artes, 1996; ANDRADE, Carlos Roberto Monteiro. Barry Parker: um arquiteto inglês na cidade de São Paulo. Tese (Doutorado em Arquitetura e Urbanismo) - FAU-USP, São Paulo, 1998. 
procuramos resgatar estudos que não foram publicados, mas que trouxeram significativa contribuição para o diálogo com a história, entre eles as dissertações de mestrado dos arquitetos Hugo Massaki Segawa, Raquel Rolnik e Carlos Roberto Monteiro de Andrade. Em suma, nesta primeira parte da apresentação, esta discussão se organiza em quatro itens: 1) as interpretações históricas globalizantes, evolutivas e as ideias fora do lugar; 2) o compromisso político do arquiteto com a história das lutas sociais; 3 ) a questão urbana e a temática da cidade na história; e 4) história, arquitetura, urbanismo: o espaço interdisciplinar.

Todos os itens destacam as concepções de história presentes nesses estudos e, para cada trabalho analisado, ressaltamos sempre a concepção predominante, embora nessa amostragem se encontrem estudos que se deslocam por mais de um desses itens.

Antes de iniciar esse percurso, esclarecemos ainda que não se trata de exigir dos arquitetos conceitos e procedimentos específicos da formação do historiador, mas sim apreender em seus trabalhos a forma como se apoiam em interpretações historiográficas, a fim de buscar nesse diálogo da arquitetura com a história caminhos que ampliem nossos estudos sobre a cidade ${ }^{4}$.

\section{As concepções de história na produção dos arquitetos}

\section{AS INTERPRETAÇÕES HISTÓRICAS GLOBALIZANTES, EVOLUTIVAS E AS IDEIAS FORA DO LUGAR}

Todos os estudos escolhidos baseiam sua interpretação da cidade em uma análise econômica, política e social determinada. São ainda essas estruturas interpretativas que delineiam a sequência das formas arquitetônicas, os traçados das ruas, os edifícios e os jardins. Entre os muitos autores que trabalham com essa perspectiva de uma história globalizante está

4 Verificar também o artigo: BRESCIANI, Maria Stella Martins. História e historiografia das cidades, um percurso. In: FREITAS, Marcos César de (Org.). Historiografia brasileira em perspectiva. São Paulo: Ed. USF-Contexto, 1998, p. 237-258. 
o arquiteto e sociólogo Nestor Goulart Reis Filho. Em sua importante obra Contribuição ao estudo da evolução urbana do Brasil, o autor acompanha o processo de urbanização no Brasil a partir dos mecanismos de subordinação que caracterizavam a relação colônia-metrópole. Em seu trabalho, a história e a sociologia estão presentes e ambas se articulam em um sistema de interpretação global ancorado no conceito de urbanização formulado pelo sociólogo Max Weber, em seus estudos sobre a cidade. Segundo Nestor Reis Filho, o processo de urbanização ocorre

[...] quando em uma sociedade existe uma divisão social do trabalho, em caráter permanente, de sorte que uma parcela ponderável da população deixa de se dedicar à produção de alimentos e passa a depender, para a sua subsistência, dos produtos do trabalho de outra parcela, aos quais tem acesso por meio de troca ou por apropriação direta. A urbanização se dá com o aparecimento de uma "economia urbana" como define Weber; portanto, com o estabelecimento do mercado urbano 5 .

Nesta perspectiva de análise economicista, referendada pelos trabalhos de Celso Furtado - mas também subsidiária dos estudos de Caio Prado Jr. com forte ênfase no campo conceitual marxista para as relações de produção -, a história é chamada a explicar os fatos urbanísticos e arquitetônicos relacionados ao binômio colonizadores versus colonos. Embora afirme não se tratar de um processo mecânico de análise, Nestor Goulart Reis Filho opera com uma sequência de movimentos pautados pela noção de causa-efeito. Assim, seus personagens “opressores", representados nesta obra pelos donatários, vereadores, representantes da coroa portuguesa, e "oprimidos", os escravos e indígenas, impulsionam o motor da história que é, sem dúvida, a luta de classes. Para Reis Filho, a história das cidades é parte de uma análise mais ampla que envolve o conjunto da humanidade e exige o método de estudo em escalas que vão do geral ao particular:

[...] a história global da urbanização, a história da urbanização no país que se estuda, que é a escala em que, no mundo

5 REIS FILHO, Nestor Goulart. Contribuição ao estudo da evolução urbana do Brasil (15001720). São Paulo: Pioneira - EDUSP, 1968, p. 20. 
contemporâneo, se definem as estruturas de poder e de controle da produção e as relações de classe ${ }^{6}$.

O livro São Paulo: três cidades em um século, de autoria do arquiteto Benedito Lima de Toledo, é referência nos estudos da história da urbanização na cidade de São Paulo. O autor se baseia em uma série de documentos, fotos e relatos de viajantes para acompanhar as transformações urbanas da capital paulista nas décadas iniciais do século, tendo como suportes a história e a memória. Retoma elementos da cidade colonial e seria, a seu ver, na carta escrita pelo Morgado de Mateus ao Marquês de Pombal, em 1786, que se encontraria a melhor descrição da "cidade de barro" ou da "cidade de taipa". O Morgado de Mateus inicia sua carta dizendo:

Está edificada a cidade de São Paulo, no meio de uma grande campina em sítio um pouco elevado, que a descobre todo em roda. O seu terreno é brando e tem ruas planas, largas e direitas e algumas bem compridas, porém, não são calçadas, todas as paredes dos edifícios são de terra, os portais e alisares de pau, por ser muito rara a pedra.... ${ }^{7}$

Após acompanhar descrições e selecionar as fotos e os mapas, Lima de Toledo registra as construções e, ao mesmo tempo, as destruições sofridas pela cidade de São Paulo no decorrer de séculos, para enfatizar a reconstrução da "cidade palimpsesto" - "raspada de tempos em tempos" e reconstruída sobre si mesma no último século. Em cada momento do longo período da Colônia ao Império, a história se dispõe como sequência linear para grandes construções, como igrejas, as escolas, os edifícios públicos e as residências burguesas, estruturando a memória da cidade pela descrição e relatos das autoridades públicas, médicos e viajantes estrangeiros. Estes relatos, por sua vez, transferem ao leitor a ideia de uma evolução natural e sem a presença de conflitos.

Dessa forma, indagamos: como explicar as transformações no espaço urbano sem associá-las aos interesses sociais e políticos que

6 Id.

7 TOLEDO, Benedito Lima de. São Paulo: três cidades em um século. São Paulo: Duas Cidades, 1981, p.15. 
marcaram fases distintas da história da cidade em diálogo com a análise das práticas das intervenções urbanas subordinadas ao seu campo conceitual especializado?

Entre os trabalhos mais recentes sobre as transformações ocorridas na cidade de São Paulo no período que abarca o Império e parte do período Republicano, o recente estudo do arquiteto Cândido Malta Campos reúne um vasto acervo de documentos sobre a cidade, entre eles, mapas, fotos, planos, projetos urbanísticos, relatórios de prefeitos, anais da Câmara Municipal e artigos de revistas especializadas da primeira metade do século XX, tais como, o Boletim do Instituto de Engenharia, a Revista Politécnica, a Arquitetura no Brasil e a Revista do Arquivo Municipal. No estudo, o autor busca apontar os conflitos políticos e econômicos que marcaram os projetos e as intervenções urbanas ao longo das primeiras décadas do século XX em São Paulo, alicerçando sua análise no paradigma da importação de ideias e de modelos estrangeiros. Acompanha, desse modo, os argumentos usados na época pelos próprios técnicos e autoridades públicas, com o intuito de convencer os interlocutores pela lógica dos bons resultados ou persuadilos por meio de imagens exemplares associadas à noção de progresso. $\mathrm{Na}$ opinião de Cândido Malta Campos,

[....] duas faces do modelo agroexportador se expressavam em diferentes orientações urbanísticas: a vertente importadora, exemplificada pela reforma Passos no Rio de Janeiro, tenderia a preferir padrões "dependentes", atrelados ao paradigma haussmanniano; a vertente produtiva e exportadora ganhava peso em São Paulo, com Víctor Freire, e, em Santos, com Saturnino de Brito, abrindo espaço para soluções mais "autônomas" e atualizadas. Ambas marcadas por visões parciais e excludentes e pela contradição entre veleidades representativas, necessidades funcionais e interesses comerciais a serem atendidos ${ }^{8}$.

Como conclusão, Cândido Malta afirma que estes dois modelos urbanísticos de matriz externa, um diretamente importado, outro adaptado 
e atualizado, estavam em desacordo com a política liberal e comercial inerentes à condição agroexportadora do país.

Importa esclarecer algo de extrema importância sobre a trajetória dos estudos dos arquitetos contemporâneos até aqui apresentados e a eles somar os que se dedicaram a esses estudos nas últimas décadas do século $\mathrm{XX}$ : estudar a cidade e acompanhar suas transformações significa configurar uma base para planejar e se possível solucionar os eventuais problemas de gestão do espaço urbano 9 . Nesses trabalhos, seus autores se preocupam com o futuro das cidades, ou seja, o estudo da história constitui um aporte pragmático em apoio de suas próprias pesquisas sobre "a evolução urbana" nos diferentes momentos das modificações na arquitetura, nos processos construtivos e no traçado da cidade. A ênfase recai na busca de respostas e soluções capazes de diminuir as "tensões sociais" inerentes ao crescimento desmesurado das cidades. Este é o traço que estrutura também os estudos voltados para a questão da habitação popular no Brasil.

Na mesma trilha de Lima de Toledo, encontramos os trabalhos do também arquiteto Carlos A. C. Lemos. Ambos fazem uso de várias fontes históricas, entre elas depoimentos de viajantes, de estrangeiros, de antigos alunos da Faculdade de Direito, de estudantes da antiga Escola Politécnica de São Paulo (fundada em 1893) e de jornalistas que se mostram perplexos com o progresso da Pauliceia. Em seu livro fundamental Alvenaria burguesa, Lemos - artista plástico e ativo militante das questões relativas à preservação do patrimônio cultural no Brasil - apresenta e analisa as diferentes fases da arquitetura residencial paulista. Apesar de manifestar preocupação com os problemas sociais e de ter dedicado um enorme espaço para discussões sobre a moradia para a população de baixa renda, constatamos em seu texto a mesma concepção evolutivo-linear da história da cidade e a ausência dos conflitos sociais. Apoiado nessa linha de interpretação histórica, Lemos apresenta as transformações ocorridas na cidade de São Paulo pelo movimento que acompanha a implantação das ferrovias e o desenvolvimento da agricultura cafeeira, num primeiro momento, seguido da introdução da mão de obra estrangeira e, por fim, pela industrialização.

9 Sabemos que uma das características marcantes da chamada arquitetura contemporânea é avaliar as consequências da presença do urbanismo racionalista que começa a ganhar corpo na segunda metade do século passado com o Plano Haussmann, Cidade-Industrial de Tony Garnier até chegar na Carta de Atenas, redigida pelo prestigiado Le Corbusier no Congresso Internacional dos Arquitetos (1933). 
Nessa perspectiva, a história serve de suporte necessário e incontestável, repleto de conceitos que cristalizam no tempo, um passado fragmentado, mas possivelmente "recuperável" pelos historiadores. Outro aspecto importante na obra de Carlos Lemos constitui o tratamento das fontes documentais: ao analisar os programas de combate aos cortiços, recorre a uma série de depoimentos médicos que atestam as implicações morais e higiênicas desse tipo de moradia. Contudo, o autor se limita a reproduzir as costumeiras imagens degradantes de cortiço e traz em apoio de seus argumentos um filme que retrata a situação:

[...] não pode deixar de ser visto um documento do início dos anos quarenta, de autoria do cineasta Benedicto Duarte, que nos mostra em pleno funcionamento um antigo cortiço da zona do Brás, ainda existente naquela data, pelo qual a gente pode aquilatar a extensão da promiscuidade típica desses aglomerados, com suas crianças seminuas brincando na sujeira da rua interna, suas mulheres cozinhando nas portas dos cubículos, suas roupas penduradas em cordas que cruzavam em todos os sentidos o espaço livre descoberto, estreito e sem sol $^{10}$.

Trazemos essa citação para chamar a atenção para os procedimentos de utilização dos relatos e que, por representarem exatamente quase a única fonte de recursos na recuperação das marcas do tempo, constituem memórias associadas a significados coletivos que ultrapassam a lembrança individual. Recordamos as reflexões de Maurice Halbwachs quando afirma ser a memória a reconstrução do passado composta com a ajuda de dados presentes e organizada por outras reconstruções feitas em épocas anteriores, também elas alteradas em suas várias reconstruções ${ }^{11}$.

\section{O COMPROMISSO DO ARQUITETO E A HISTÓRIA DAS LUTAS SOCIAIS}

Em posição analítica diferenciada, importa destacar os estudos que suspeitam, confrontam e ainda estabelecem um diálogo com as fontes

10 LEMOS, Carlos. Alvenaria burguesa. 2. ed. São Paulo: Nobel, 1989, p. 65.

11 HALBAWACHS, Maurice. A memória coletiva. São Paulo: Vértice, 1990, p. 65. 
consultadas, tais como os textos publicados em 1980 na coletânea As lutas sociais e a cidade, organizada pelo sociólogo Lúcio Kowarick. Importa lembrar sobre o momento político da publicação dessa coletânea, marcado pelos movimentos sociais desses anos 80 , em especial o movimento dos trabalhadores em São Bernardo do Campo, em São Paulo, com destaque para a criação e atuação do Partido dos Trabalhadores. Preocupados com estudar a formação das diversas experiências de luta e plataformas de reivindicação dos grupos populares que se organizavam, sociólogos e arquitetos dedicaram seus estudos às lutas sociais urbanas, problematizando o presente e a partir de uma interpretação histórica menos comprometida com os esquemas ou categorias econômicas determinantes ${ }^{12}$.

Retomo, para ficar entre os autores arquitetos, o artigo sobre a crise da habitação em São Paulo do arquiteto Nabil Bonduki. As trilhas e os vestígios deixados pelos jornais e revistas, ao lado da consulta aos Anais da Câmara de Deputados na década de 1940, foram trabalhados por ele no sentido de descerrar o significado e o espaço de reivindicações da população de baixa renda frente ao problema habitacional, entre o pós-Primeira Guerra e o fim do Estado Novo. Nesse artigo, como em outros dessa mesma coletânea, a preocupação com a reconstituição histórica dos movimentos sociais expõe o conflito e a luta entre diferentes setores da sociedade. Além disso, introduz a questão da moradia e do direito a melhores condições de vida no amplo debate das implicações decorrentes da forma de ocupação e gestão da cidade. A perspectiva teórica e metodológica adotada por Bonduki coincide com a que subsidia os estudos da arquiteta Raquel Rolnik para o período da industrialização em São Paulo. Em sua dissertação de mestrado, a arquiteta faz uma leitura inovadora do espaço urbano a partir dos conflitos entre diferentes setores da sociedade, entendendo que somente a história "minúscula" seria capaz de focalizar o palco das tensões e dos conflitos. Os livros de história, argumenta, esclarecem muita coisa e, no entanto, “[...]

$12 \mathrm{O}$ arquiteto e urbanista Nabil Bonduki desenvolveu vários estudos referentes à política habitacional, política urbana, movimentos sociais, condições de moradia e urbanismo. Tem vários livros publicados, entre os quais Origens da habitação social no Brasil (Estação Liberdade, 1998) e vários artigos em livros, periódicos e veículos de comunicação social. Além disso, atuou como Superintendente de Habitação Popular do município de São Paulo (1989-92), tendo coordenado o Programa de Habitação de Interesse Social do município, e foi vereador do município de São Paulo (2001-2004), quando coordenou a elaboração do substitutivo do Plano Diretor Estratégico do Município de São Paulo e os Planos Regionais das 31 subprefeituras do município. 
seu relato é apenas uma das formas de se lembrar o passado, geralmente estruturada em torno de 'marcos', fatos e indivíduos notáveis ${ }^{13}$ ".

A história que a autora denomina "minúscula" se encontraria nos jornais e nos documentos com os quais, no seu entender, devemos trabalhar com alguns cuidados, porque "[...] tanto em jornais como em documentos, a forma básica de registro - o texto escrito - seleciona tanto o autor como o público, expressando portanto o ponto de vista da minoria que produz e lê palavras escritas ${ }^{14 \%}$.

Em seu estudo, Ralquel Rolnik reivindica a reconstituição da história em diálogo com a arquitetura ao entrecruzar a leitura de mapas, fotos, romances e a memória de antigos moradores dos bairros operários. Por outro lado, descerra a reflexão histórica sobre o poder das autoridades médicas frente às práticas populares, permite relacionar história e memória e estabelecer outro vínculo entre história e arquitetura, além de trabalhar com as noções de tempo/espaço sob vários ângulos, a partir de cortes transversais. Em lugar de um movimento linear e evolutivo, a autora acompanha vários momentos históricos por meio das diferentes práticas discursivas.

\section{A QUESTÃO URBANA E A TEMÁTICA DA CIDADE NA HISTÓRIA}

Contudo, o aprofundamento e o adensamento das pesquisas permitiram a formulação de outras perspectivas importantes para os estudos sobre cidades, bem como deram lugar a outros campos de investigação, especialmente em nível pós-graduado, como a pioneira linha de pesquisa em história então denominada Cultura e Cidades ${ }^{15}$. Os debates formulados, advindos dessa perspectiva, ensejaram propostas de estudos que, até certo

13 ROLNIK, Raquel. Cada um no seu lugar! São Paulo, início da industrialização: geografia do poder. Dissertação (Mestrado em Arquitetura e Urbanismo) - FAU-USP, São Paulo, 1981.

14 Ibid., p. 1. Parece-nos que a autora se refere à concepção da história atrelada aos fatos e nomes, provavelmente relativa aos critérios do ensino de história que até então eram apresentados nos livros didáticos.

15 É no final de 1980 que começam a se organizar grupos de pesquisa, área e temática específicas sobre Cidades nos programas de pós-graduação em história. A linha então denominada Cultura e Cidades passa a constar do programa de Pós-Graduação em História Social na Unicamp em 1985. Atualmente possui outra configuração, conforme veremos adiante. 
ponto, definiram "outros caminhos" na pesquisa e reflexão sobre as questões urbanas, cujos elementos de significativa repercussão podem ser ilustrados pelo artigo da historiadora Maria Stella Bresciani "Permanência e ruptura no estudo das cidades"16, completado posteriormente por "As sete portas da cidade" 17 .

Dentre a leitura da produção de autores que se preocuparam e refletiram sobre temas urbanos, ressalto a importância dos textos constitutivos da base conceitual da linha de pesquisa Cultura e Cidade: Frederich Engels, A situação da classe trabalhadora na Inglaterra (primeira edição em 1845); Walter Benjamin, Sobre alguns temas em Baudelaire, Paris capital do século XIX, $O$ trabalho das passagens, para só mencionarmos alguns de seus escritos no período entre as duas grandes guerras mundiais; Françoise Choay, Urbanismo - utopias e realidades (originalmente publicado em 1964) e François Béguin, "As maquinarias inglesas do conforto" (publicado inicialmente em 1977). Essa múltipla entrada no tema permitiu apreender a cidade de forma multifacetada e deslocar a interpretação que estabelecia relação "causa-efeito" entre industrialização, crescimento demográfico e questão urbana, predominante nos estudos sobre as cidades no século XIX e $\mathrm{XX}^{18}$.

A contribuição da filósofa Françoise Choay foi essencial: indicou a íntima relação entre posições político-filosóficas e a leitura das cidades e o rebaixamento desse vínculo quando o urbanismo, ao se tornar um campo disciplinar no início do século XX, reivindica apoiar-se na técnica e no saber especializado. Na apresentação da antologia de textos selecionados, afirma a persistência de opções entre campos conceituais formadores do "pré-urbanismo" do século XIX ao longo do século XX. François Béguin, por sua vez, percorre caminhos propostos por Michael Foucault em dois

16 BRESCIANI, Maria Stella. Permanência e ruptura nos estudos da cidade. In: FERNANDES, Ana; GOMES, Marco Aurélio de Filgueiras (Orgs.). Cidade e História: modernização das cidades brasileiras nos séculos XIX e XX. Salvador: FAU-UFBA, 1992, p. 11-26.

17 BRESCIANI, Maria Stella. As sete portas da cidade. Espaço \& Debates. Dossiê Cidade e História. São Paulo: NERU, ano XI, n. 34, 1991.

18 ENGELS, Friedrich. A situação da classe trabalhadora em Inglaterra. Porto: Afrontamento, 1975; BENJAMIN, Walter. Walter Benjamin: sociologia. Tradução e organização Flávio R. Kothe. 2. ed. São Paulo: Ática, 1991; CHOAY, Françoise. O urbanismo: utopias e realidades - antologia. São Paulo: Perspectiva, 1979; BÉGUIN, François. As maquinarias inglesas do conforto. Espaço \& Debates, Dossiê Cidade e História. São Paulo: NERU, ano XI, n. 34, 1991, publicado originalmente na revista Recherches, CERF, n. 29, 1978. 
de seus livros - Microfísica do poder e Vigiar e punir - e introduz como elemento crucial para entender as intervenções em cidades do século XIX as pesquisas efetuadas na França e na Inglaterra por médicos e autoridades públicas ${ }^{19}$. Béguin propõe terem essas pesquisas dado lugar à formulação da questão urbana ou problematização da cidade enquanto questão técnica a partir de noções sanitárias que implementaram novas estratégias de intervenção no meio urbano, dentre elas a eliminação de locais insalubres e comprometedores da salubridade da cidade: cemitérios, matadouros, hospitais e as precárias moradias da população pobre ${ }^{20}$. Em sua análise, Béguin mostra como as pesquisas feitas na Inglaterra contribuíram para demonstrar, a partir da perda de produtividade do trabalhador, o custo econômico e social da miséria e os prejuízos causados pela doença à economia britânica.

Essa perspectiva teórica ampliou, já nos inícios dos anos 1990, os estudos de historiadores e sociólogos sobre a cidade e possibilitou uma série de trabalhos voltados para a temática da moradia operária, do sanitarismo, engenharia, arquitetura, urbanismo, memória e patrimônio histórico em São Paulo, como em outras cidades do Brasil ${ }^{21}$.

19 FOUCAULT, Michael. Microfisica do poder. Rio de Janeiro: Graal, 1986; punir: nascimento da prisão. Petrópolis: Vozes, 1983. Os relatórios apresentados pela equipe de Chadwick procuravam demonstrar ao Estado, através de dados estatísticos, as vantagens políticas e econômicas oferecidas pela implantação dos sistemas de canalização de água e através da instalação das redes de esgoto na cidade. Estes relatórios, acompanhados pela ameaça de uma nova epidemia de cólera, contribuíram na constituição da primeira lei sanitária e urbana aprovada na Inglaterra em 1848. Cf. BRESCIANI, Maria Stella Martins, "A questão urbana, técnica e política" (texto apresentado para discussão no grupo de pesquisa sobre cidades da ANPUH-Núcleo São Paulo, sessão de 29/03/1998).

$20 \mathrm{Id}$.

21 Como exemplos, temos os estudos: CARPINTÉRO, Marisa. A construção de um sonho: os engenheiros, arquitetos e a formulação da política habitacional no Brasil 1917-1940. Dissertação (Mestrado em História Social) - IFCH-Unicamp, Campinas, 1997; SAMPAIO, Maria Ruth Amaral de. A promoção privada de habitação econômica e a arquitetura moderna 1930-1964. São Paulo: Rima Editora, 2002; MONTÓIA, Ana Edite Ribeiro. Cidade e Política: São Paulo no século XIX. Dissertação (Mestrado em História Social) - IFCH-Unicamp, Campinas: 1990; LOPES, Myrian Bahia. Práticas médico-sanitaristas e remodelação urbana na cidade do Rio de Janeiro. Dissertação (Mestrado em História Social) - IFCHUnicamp, Campinas, 1986; LOPES, Myrian Bahia. Les Corps Inscrits. Vaccination antivariolique et biopouvoir. Londres-Rio de Janeiro: 1840-1904. Tese (Doutorado em Sociétés Occidentales) - Université de Paris VII; Université Denis Diderot, 1997; VEIGA, Cynthia Greive. Cidadania e educação na trama da cidade: a construção de Belo Horizonte em fins o séc XIX. Tese (Doutorado em História) - IFCH-Unicamp, Campinas, 1994 (publicado pela EDUSF em 2003). Além desses, os estudos desenvolvidos pelos profissionais da Fundação Oswaldo Cruz, Rio de Janeiro, os artigos publicados em: CUNHA, Maria Clementina P. (Org.). O direito à memória: Patrimônio Histórico e Cidadania. São Paulo: DPH/SMC, 1992; a coletânea organizada pelo sociólogo Robert Pechman com artigos de vários historiadores, arquitetos e filósofos (PECHMAN, Robert Moses. Olhares sobre a cidade. Rio de Janeiro: IPPUR-UFRJ, 1992), o dossiê Cidades (Revista 
Da mesma forma, essa nova aproximação historiográfica das cidades esteve presente nos encontros, simpósios e congressos ocorridos no Brasil ao longo de quase três décadas e aproximaram arquitetos e historiadores colocando desafios, provocando debates no conjunto das interpretações históricas nos estudos da cidade $^{22}$. Com sua dissertação de mestrado Construções de ordens: um aspecto da arquitetura no Brasil, 1808-1930, de 1987, o arquiteto Hugo Segawa já entrara nesse debate ao descortinar a complexa teia que encobre os projetos políticos e sociais das produções arquitetônicas no decorrer do século XIX e início do XX, entre elas hospitais e hospícios, a hospedaria de imigrantes, as escolas e penitenciárias ${ }^{23}$. Ao trabalhar com certas tipologias arquitetônicas que denomina como "genealogia das tipologias", Segawa acompanha com uma vasta documentação o debate entre técnicos, políticos brasileiros e estrangeiros partidários do projeto de modernização social, segundo ele, detonado no final do século XVIII. Além de discutir as concepções de espaço presentes no conjunto dos projetos urbanísticos apresentados no início do século XX para as principais cidades brasileiras, importa salientar neste trabalho a substituição de uma trilha evolutiva por uma análise histórica comparativa das cidades em diferentes temporalidades. Segawa mantém uma instigante relação com os tempos da história e mostra como essas estratégias nascem com a chamada "Idéia Sanitária", em suas dimensões moral e física, o que faz com que médicos higienistas e engenheiros sanitaristas sejam, ao mesmo tempo, atores e autores desta política de gestão urbana. Completa seu trabalho a avaliação da importância dos programas arquitetônicos nas construções de obras especializadas para atender determinadas funções, como: matadouros, açougue, mercados, hotéis, botequins, tavernas, casas de negócio, teatros e espaços de divertimento públicos.

Brasileira de História. ANPUH, v. 27, n. 53, 2007) e trabalhos recentes como: CERASOLI, Josianne Francia. A Grande Cruzada: os engenheiros e as engenharias de poder na Primeira República. Dissertação (Mestrado em História Social) - IFCH-Unicamp, Campinas, 1998; CERASOLI, Josianne Francia. Modernização no plural: obras públicas, tensões sociais e cidadania em São Paulo na passagem do século XIX para o XX. Tese (Doutorado em História) - IFCH-Unicamp, Campinas, 2004.

22 Consultar a Revista Pós, número especial. Anais do Seminário Nacional - FAU/USP, 1994, $O$ estudo da História na formação do arquiteto, textos apresentados em conferências e mesas redondas e comunicações do Seminário Nacional promovido pelo Departamento de História da Arquitetura e Estética do Projeto. Este Seminário aconteceu com o intuito de aprofundar as questões referentes ao estudo da história na formação do arquiteto.

23 SEGAWA, Hugo. Construções de ordens: um aspecto da arquitetura no Brasil 1808-1930. Dissertação (Mestrado em Arquitetura e Urbanismo) - FAU, USP, São Paulo, 1987. 
A construção da cidade na etapa inicial da República no Brasil também foi tema abordado pelo arquiteto Carlos Roberto Monteiro de Andrade em sua dissertação de mestrado $A$ peste e o plano: o urbanismo sanitarista de Saturnino de Brito ${ }^{24}$. Em seu estudo, acompanha os projetos implementados pelo engenheiro sanitarista Saturnino de Brito em várias cidades brasileiras que, diz o autor, além de sanear as cidades tomadas ou ameaçadas por epidemias, elaborava planos de extensão e, ao mesmo tempo, como se dizia então, "aformoseava a paisagem da cidade" criando uma imagem urbana moderna. Ao privilegiar o discurso do engenheiro sanitarista, a linguagem escrita e gráfica dos relatórios, planos de extensão e projetos de saneamento, definidos por Andrade como "textos ligados às práticas do ofício", o autor penetra na rede de relatos que, por sua vez constitui a análise crítica e interpretativa do discurso de Brito.

\section{HISTÓRIA, ARQUITETURA, URBANISMO: O ESPAÇO INTERDISCIPLINAR}

Outros estudos, desenvolvidos na década de 1990, trouxeram à tona estimulantes caminhos relativos ao diálogo da história com a arquitetura. Ao perseguir a prática e os fundamentos teóricos do urbanismo através da trajetória profissional de professores e ex-alunos da Escola Politécnica de São Paulo, alguns estudos procuravam o olhar crítico da história urbana para entender o processo de transformação da capital paulista ${ }^{25}$. Essa perspectiva possibilitou descerrar o véu que encobria a teia de relações entre o corpo técnico de engenheiros, sobretudo os formados pela Escola Politécnica de São Paulo, e a administração municipal, e contribuiu também para a leitura do processo de construção da metrópole nos anos 1950.

As pesquisas das arquitetas Regina Meyer e Maria Cecília Loschiavo dos Santos marcaram esse diálogo, introduzindo a importância

24 ANDRADE, Carlos Roberto Monteiro. A peste e o plano: o urbanismo sanitarista de Saturnino de Brito. Dissertação (Mestrado em Arquitetura e Urbanismo) - FAU, USP,São Paulo, 1992. Saturnino de Brito; um projetista de cidade. Arquitetura e Urbanismo, ano 12, n. 72, jun./jul., 1997.

25 SANTOS, Maria Cecília Loschiavo. Escola Politécnica 1894-1984. São Paulo: Escola Politécnica-Fundação para o Desenvolvimento Técnico da Engenharia, 1985; MEYER, Regina M. P. Metrópole e urbanismo - São Paulo, anos 50. Tese (Doutorado em Arquitetura e Urbanismo) - FAU, USP, São Paulo, 1991. 
da interdisciplinaridade nos estudos da cidade na área dos trabalhos dos arquitetos. Podemos encontrar nesse diálogo um questionamento que procura não somente entrelaçar saberes, mas fixar, sobretudo, incertezas e desconfianças, na busca de conhecimentos a serem trabalhados, para se compreender o sentido das rupturas e permanências dos problemas vividos na metrópole paulista. Os estudos de Loschiavo sobre a história da Politécnica incrementaram o debate com a história e ainda instigaram Sylvia Ficher em sua pesquisa sobre Os arquitetos da Poli: ensino e profissão em São Paulo ${ }^{26}$. No livro a autora apresenta um amplo estudo sobre o ensino de arquitetura e a constituição da história da Escola Politécnica em São Paulo. Além de acompanhar o ensino a formação dos engenheiros-arquitetos da Politécnica, Ficher apresenta a biografia profissional de alguns de seus professores e ex-alunos até a metade do século XX. Outro aspecto a se destacar nesse trabalho é o debate entre esses profissionais no tocante às posições políticas e acadêmicas, bem como frente à regulamentação da profissão de engenheiroarquiteto, com a fundação de instituições e associações de classe.

Outro trabalho merece referência particular. Trata-se da pesquisa de Sarah Feldman para seu livro Planejamento e zoneamento ${ }^{27}$, sobre o processo de urbanização da cidade de São Paulo no período de 1947 a 1972. Os textos e trabalhos publicados pelos urbanistas vinculados à administração municipal de São Paulo, os planos urbanísticos, os relatórios de prefeito, os artigos de jornais, atos, leis e decretos municipais, somados à experiência de Sarah Feldman, que durante quinze anos atuou como profissional urbanista na administração municipal de São Paulo, resultaram nesse cuidadoso estudo. Nele, a autora procura reconstruir as ideias e práticas relacionadas à implantação do zoneamento na capital paulista pelo setor de urbanismo da prefeitura. Para essa autora, a história é reconstrução, é problema, é uma viagem marcada por vários movimentos históricos tecidos a partir das diferentes práticas discursivas. Permanências e rupturas desvendam nesse estudo as práticas do planejamento urbano em São Paulo, apontam seus conflitos, desvelam a cidade e seus agentes e descortinam a formação do campo conceitual do saber urbanístico. EDUSP, 2005.

26 FICHER, Sylvia. Os arquitetos da Poli: Ensino e profissão em São Paulo. São Paulo:

27 FELDMAN, Sarah. Planejamento e zoneamento. São Paulo, 1947-1972. São Paulo: EDUSP/FAPESP, 2005. 
O caminho da interdisciplinaridade também estimula interessantes estudos envolvendo arquitetos, sociólogos e historiadores nos temas relacionados à problemática da habitação popular em São Paulo, como é o caso da coletânea organizada pela socióloga Maria Ruth Amaral de Sampaio A promoção privada de habitação econômica e a arquitetura moderna, 1930 $-1964^{28}$. Cabe esclarecer que esta coletânea apresenta parte dos resultados obtidos no decorrer do projeto temático Habitação econômica e arquitetura moderna no Brasil - 1930/ 1964, desenvolvido na Faculdade de Arquitetura e Urbanismo e no Departamento de Arquitetura da Escola de Engenharia de São Carlos da Universidade de São Paulo. Trata-se de um projeto que procurou analisar e identificar a produção da habitação econômica, coletiva, promovida pela iniciativa privada, desenvolvida sob os princípios do movimento moderno. A análise crítica da documentação, as interpretações históricas distantes dos marcos centrados nas relações de "causa-efeito", a preocupação com a definição dos conceitos relativos à "habitação econômica", "habitação coletiva", "movimento moderno de arquitetura" e com a leitura dos projetos arquitetônicos, são características essenciais presentes nos artigos apresentados pelos autores dessa coletânea.

Como vemos, são muitos esforços e concepções de história que atravessam os estudos dos arquitetos: há a história evolucionista e linear e/ou quando apoiados nas teorias das "idéias fora do lugar" - que abordaremos mais detidamente adiante - trazem as noções de importação, transplante ou reformulação das teorias urbanísticas e dos modelos arquitetônicos estrangeiros pelos profissionais brasileiros, mas por outro lado há também tentativas de se operar com temporalidades e relações mais complexas, que apontam para a necessidade de se ousar ainda mais nas aproximações entre os campos da arquitetura e da história. Se para os arquitetos a história se coloca como instrumento importante para os estudos da cidade, devemos, como eles, aprender a percorrer os mapas, fotos e planos e lembrar que as mudanças das formas e das cores do traçado de vias públicas e edificações exibem as diversas camadas sobrepostas do tempo. Assim, cada leitura do espaço sempre será um novo desafio para o historiador, cada marca deixada pelas transformações urbanas proporciona novas pistas e, com elas, a possibilidade de reconstruir outras tramas. 


\title{
II. A cidade sob uma grande angular: abordagens do urbano na historiografia
}

\author{
Objetos perdidos: o que torna tão incomparável e tão irrecuperável a \\ primeiríssima visão de uma aldeia, de uma cidade na paisagem, é que nela a \\ distância vibra na mais rigorosa ligação com a proximidade. O hábito ainda não fez sua \\ obra. Uma vez que começamos a nos orientar, a paisagem de um \\ só golpe desapareceu, como a fachada de uma casa quando entramos. \\ Ainda não adquiriu uma preponderância através da investigação \\ constante, transformada em hábito. Uma vez que começamos a nos \\ orientar no local, aquela imagem primeira não pode \\ nunca mais restabelecer-se. \\ W. Benjamin. Rua de mão única.
}

Qual o lugar que as cidades ocupam e como têm sido interpretadas na narrativa dos historiadores? Se as concepções de história presentes no conjunto dos estudos sobre as cidades modernas formuladas a partir do campo disciplinar da arquitetura e do urbanismo são multifacetadas e acentuadas por alternâncias, entre permanências e rupturas, o deslindamento das cidades como matéria do campo da história não nos deixa rastros mais lineares. As abordagens são numerosas, proporcionais à quantidade de pesquisas sobre questões urbanas constantes na historiografia, apesar da relativa novidade da temática que apenas na década de 1980 veio a se tornar efetivamente pauta dos estudos históricos no Brasil. O breve percurso proposto não faz uma avaliação sistemática e exaustiva de toda a pesquisa historiográfica que tematiza a cidade e o urbano, considerando-se, inclusive, o elevado volume dessa produção no Brasil, sobretudo a partir da década de $1990^{29}$. Trata-se de uma reflexão menos pontual, mais abrangente

29 Há pelo menos dois panoramas sobre os percursos da historiografia sobre cidades, ambos datados da década de 1990: Raminelli, que avalia a formação de um campo de investigação e perfaz um interessante percurso sobre contribuição da análise sociológica, de base filosófica, para os estudos urbanos (passando por Simmel, Mumford, Weber, entre outros); e Bresciani, que reflete sobre a constituição da questão urbana a partir do século XIX e sobre a historiografia que investiga a cidade, elaborada a partir da década de 1980, com destaque para as pesquisas sobre São Paulo, tomando como referência os percursos de pesquisa relacionados às linhas de pesquisa histórica em que atua. RAMINELLI, Ronald. História Urbana. In: CARDOSO, Ciro Flamarion; VAINFAS, Ronaldo (Orgs.). Domínios da História: ensaios de teoria e metodologia. Rio de Janeiro: Campus, 1997, p. 185-202; BRESCIANI, M. S. M. História e historiografia das cidades, um percurso. In: FREITAS, Marcos César de (Org.). Op.cit. 
- à maneira de uma imagem captada por uma grande angular -, sobre as escolhas dessa historiografia, cujos resultados apontam paradoxalmente para presenças da cidade, apesar de constantes, muito esmaecidas nesses estudos. Nota-se, no mapeamento das pesquisas no campo disciplinar da história, a preponderância de abordagens aqui entendidas como indiretas em relação à cidade, como se os estudos operassem certos "desvios" a partir do tema. Emprestamos as metáforas de Walter Benjamin na passagem acima e veremos como a historiografia sobre cidades no Brasil, quando começa a se aproximar de seu objeto, a se orientar, como que deixa escapar a paisagem urbana vista de um só golpe à distância, tal como "a fachada de uma casa quando entramos". Para isso, analisaremos alguns dados indicativos da produção do conhecimento histórico no Brasil relativos ao desenvolvimento da pesquisa nesse campo, e em seguida ajustaremos o foco para comentar criticamente algumas abordagens que têm merecido destaque nessa paisagem, sobretudo em relação aos estudos que advogam uma matriz cultural de análise. Por fim, colocaremos em questão as imagens de cidade construídas pelos historiadores, a partir daquilo que denominamos paisagens culturais e sociais, analisadas nas pesquisas voltadas ao entendimento da modernização - tema destacado entre os estudos acadêmicos sobre a urbe no campo da história. A noção de paisagem, nesse caso, responde menos a acepções literais ou a conceituações precisas, historicamente constituídas; é mais uma metáfora transposta para outros sentidos possíveis - a aproximação entre cidade e paisagem, entrecruzada por aspectos sociais e culturais nos estudos históricos, pode sugerir antecipadamente à imaginação a ideia de um quadro tomado à distância, um cenário para um enredo, um pano de fundo ${ }^{30}$.

30 Entre as abordagens sobre a noção de paisagem a partir de seu conteúdo histórico, em especial sobre mudanças na percepção do mundo urbano e rural, destacam-se: WILLIAMS, Raymond. Plaisantes Perspectives: invention du paysage et abolition du paysan. Actes de la Recherche en Sciences Sociales. $\mathrm{n}$. 17-18, p. 29-36, 1977; O campo e a cidade na história e na literatura. São Paulo: Companhia das Letras, 1989; THOMAS, Keith. O homem e o mundo natural: mudanças de atitude em relação às plantas e aos animais. Trad. João Roberto Martins Filho. São Paulo: Companhia das Letras, 1988; DAGOGNET, François (Org.). Mort du Paysage? Philosophie et esthétique du Paysage. Seyssel: Champ Vallon, 1982; PEIXOTO, Nelson Brissac. Paisagens urbanas. 3 ed. São Paulo: SENAC, 2004. Agradecemos a Stella Bresciani pelas indicações sobre a matéria histórica da paisagem. 


\section{A CIDADE NA PESQUISA HISTÓRICA: INDIRETA E OBLÍQUA PRESENÇA}

Entre as muitas possibilidades de se buscar uma imagem panorâmica da produção historiográfica sobre cidades, trazemos inicialmente informações que podem favorecer a localização e a caracterização, de modo abrangente, dos estudos sobre a temática no conjunto da pesquisa historiográfica no país, considerando-se prioritariamente estudos desenvolvidos em instituições de ensino e pesquisa. Essa opção visa, sobretudo, situar tais pesquisas em possíveis "linhagens" e buscar indícios sobre seus prováveis significados diante da abrangência de áreas temáticas que compõem o trabalho do historiador na atualidade. Reunimos inicialmente dados a partir do Diretório de Grupos de Pesquisa, desenvolvido e gerenciado pelo Conselho Nacional de Desenvolvimento Científico e Tecnológico-CNPq, e informações dos programas de Pós-Graduação em História, autorizados e avaliados pela Coordenação de Aperfeiçoamento de Pessoal em Nível Superior-Capes. O caráter oficial e referencial de ambos permite o acesso aos dados explicitados pelos pesquisadores de modo intencional e sistemático, embora seja necessário considerar a possibilidade de guardarem certa inconsistência, uma vez que um dos principais estímulos ao fornecimento desses dados ao Diretório ainda está na relevância de índices e cadastros oficiais para os sistemas de avaliação do ensino superior e para a visibilidade das instituições concernidas. Entretanto, tal possibilidade não invalida os dados nem diminui o significado da sondagem, visto que os registros partem da iniciativa dos próprios pesquisadores e devem de algum modo relacionar-se minimamente com as pesquisas feitas ou programadas. Indicam, portanto, ao menos os campos de interesse para a pesquisa na área de história.

Indireta a presença da cidade. O Diretório de Grupos de Pesquisa do CNPq é a única base de dados corrente que reúne informações sobre os grupos de pesquisa ativos no país, constituída a partir de $1992^{31}$. As orientações para classificação dos temas de pesquisa e a escolha dos

31 Todo procedimento de reunião das informações de cada grupo é de responsabilidade dos dirigentes de pesquisa e dos líderes dos grupos cadastrados também nas instituições de ensino e pesquisa. A cada dois anos, é feito um censo a partir da base corrente, que deixa registrado o momento da pesquisa no país a partir dos dados enviados ao diretório pelos pesquisadores (há censos bianuais desde 2000). 
termos ou palavras-chave para indexação de cada grupo no Diretório são determinadas pelos próprios grupos, resultando disso uma pluralidade de denominações e formas de registro, e também certa autonomia dos pesquisadores ao buscarem a terminologia e as descrições para caracterizar sua própria pesquisa. Considerando esses aspectos, buscamos no Diretório os grupos que definem em algum nível a cidade ou o urbano como palavrachave de suas pesquisas, e localizamos mais de oitenta grupos ${ }^{32}$. As temáticas e abordagens descritas são variadas: além daqueles diretamente relacionados à cidade e ao espaço urbano ${ }^{33}$, encontramos temas como sociedade e natureza, territórios, intelectuais e cultura política, imigração, cidade e poder, movimentos sociais, trabalho e poder, cidadania, violência, história regional e local, história oral, ensino, identidade, sociabilidade, sobre o uso de imagens e documentos, entre outros. Merece destaque nesses grupos a reiterada referência a três outras temáticas: estudos envolvendo questões de gênero, estudos sobre memória (alguns deles relacionando memória, identidade e espaços da cidade) e, principalmente, as pesquisas relacionadas à cultura ou identificadas como história cultura ${ }^{34}$. Um panorama amplo desses grupos indica logo de início o caráter por vezes secundário da questão da "produção" da cidade nas atividades descritas. Com frequência, a urbe é

32 Usando-se o termo cidade são recuperados 421 resultados, efetuando-se a busca em todas as áreas; 225 na grande área de ciências humanas, 132 na área de ciências sociais aplicadas; 71 na área de história. A partir do termo urbano são recuperados 618 resultados, efetuando-se a busca em todas as áreas; 240 na área de ciências sociais aplicadas; 198 na área de ciências humanas, sendo 91 em geografia e 26 em história (13 deles aparecem também na busca por cidade, ou seja, podemos falar em 84 grupos que se autoidentificam como estudos ligados à cidade e/ou ao urbano na área de história, de acordo com os cadastros do CNPq). Como utilizamos a base corrente, é importante registrar a data da pesquisa, visto que a atualização da mesma é constante (pesquisa em 12 de outubro de 2008). Embora se trate apenas de uma sondagem sem uma investigação mais detida das especificidades de cada registro enumerado, é possível a partir dela também se antever o interesse de diversos campos do conhecimento no estudo de questões relativas à cidade - 0 que alimenta o desafio de um futuro balanço de como esses saberes têm contribuído para o entendimento da questão urbana. Diante dos objetivos deste artigo, focalizamos apenas as pesquisas na área da história, que corresponde a cerca de um terço dos registros no Diretório na área de ciências humanas.

33 Entre os grupos que se identificam diretamente com estudos sobre cidades e espaços urbanos, encontramos: Núcleo de Estudos Urbanos e das Cidades - NEUCIDADES - UFT, Práticas Urbanas - UECE, Modernidade, urbanidade e relações internacionais - FURG, Metáforas concretizadas: a Grande São Paulo na segunda metade do século XX e início do XXI - USP, Cidade, tempo e espaço - UFPI, Cidade: Espaço e Cultura - UNESC, Núcleo de Estudos de História Social da Cidade - NEHSC (Antigo Grupo CORDIS) - PUC/SP, Núcleo de Estudos de Cultura e Cidade - UNEB, Cidade e Cultura - UFRGS, História Social do Trabalho e da Cidade - UNIOESTE.

34 São cerca de quinze grupos a relacionar história e cultura. 
o cenário em que se desenrola a trama da questão histórica enunciada pelo grupo, noutras é o depositário da documentação analisada, outras vezes ainda a cidade aparece apenas como o espaço no qual figuram as relações de poder (políticas, sociais, simbólicas) ou se situam os personagens. Apesar de numerosa nas referências da "busca", a presença da cidade nas temáticas parece oblíqua mesmo quando apreendida a partir da temporalidade histórica por grupos que demarcam como seu horizonte de pesquisa a contemporaneidade - no qual estaria, de modo crucial, a questão urbana ${ }^{35}$. Talvez esteja nesses grupos um primeiro indício dos desvios que apontamos neste percurso da cidade na historiografia - uma indireta presença.

É a partir da definição de cidade como tema de fundo de suas abordagens que o Núcleo de Estudos de História Social da Cidade-NEHSC, por exemplo, cadastrado regularmente no Diretório, organiza-se em torno de quatro linhas de pesquisa (sobre linguagens e cidadania; memória e cultura; saúde, doença e morte; universidade e sociedade). Entre as atividades do núcleo desenvolvidas desde a década de 1990, merece destaque a pesquisa realizada em parceria com o Museu de Saúde Pública Emílio Ribas sobre transformações urbanas e sociais na capital paulista, analisadas a partir de uma documentação de base médico-sanitária, proveniente dos acervos da Secretaria de Saúde de São Paulo ${ }^{36}$. Campanhas de saúde pública, especialmente contra a varíola, publicações de órgãos do Estado sobre saúde, questões ligadas à epidemiologia e à assistência materno-infantil, dimensões sanitárias dos sepultamentos, entre outros assuntos relacionados ao saber médico na cidade, foram inventariados e trabalhados nessa pesquisa. As perspectivas adotadas privilegiam as discussões sobre saúde, deixandonos a clara impressão de que a cidade se apresenta nesses estudos como o lugar em que se desenrola essa trama. A cidade, nas palavras de um de seus pesquisadores, apresenta-se como "cenário privilegiado para a expressão e construção de subjetividades na objetividade da confluência de saberes

35 Há ainda dois grupos que tematizam a cidade a partir das temporalidades históricas que analisam - a contemporaneidade: Laboratório de Estudos do Tempo Presente - UFRJ, Núcleo de Estudos do Contemporâneo - UFMT.

36 Projeto desenvolvido entre 2001 e 2003: “As Transformações Urbanas e Sociais da Cidade de São Paulo Através do Centro Técnico de Preservação da Memória da Secretaria da Saúde de São Paulo (1889-1972)", financiado pela FAPESP (Políticas Públicas), em parceria com o Museu de Saúde Pública Emílio Ribas, cujos resultados estão disponíveis no site: www.misp.pucsp.br, e no próprio museu. 
e poderes", como lugar de expressão da vida social e de projetos plurais ${ }^{37}$. A despeito da eleição desse tema decisivo para a configuração das cidades na contemporaneidade - a questão médico-higienista, indissociável da ideia sanitária -, permanece uma indagação a partir dos elementos dessa pesquisa: que status é atribuído à cidade, na condição de temática de estudo da história, quando a pesquisa resvala em aspectos tão fundamentais ao funcionamento e mesmo à compreensão da urbe? Estaria também operando de forma desviante, ao eleger o tema sanitário como algo que se passa na cidade, e não a constitui? Pensar sobre questões como essas pode nos ajudar a esclarecer o que pensamos como "desvio" nestas reflexões.

A cidade está velada. Outro indício importante acerca dos interesses de pesquisa encontra-se nas definições dos programas de pós-graduação em história, suas áreas de concentração e linhas de pesquisa - locus, por definição, da pesquisa acadêmica em cada campo do conhecimento. Sabemos tratar-se de uma espécie de "carta de intenções" bastante genérica e abrangente, definida a partir de critérios amplos muitas vezes capaz de acolher um repertório de pesquisas bastante variado, mesmo assim, parecenos razoável entender essas definições como registros mais duradouros, depositários de projetos de longo prazo. Permitiriam, assim, uma significativa panorâmica dos interesses de pesquisa no campo da história: é muito expressivo notar que aproximadamente a metade dos programas define a história social como sua área de concentração ${ }^{38}$, sendo em quase a totalidade deles a única área indicada; mais ou menos um quinto dos programas define a cultura como sua principal área de concentração, tomada sob perspectivas históricas (história cultural, história e culturas, história, cultura e poder, entre outros); há alguns programas que definem a questão do espaço e/ou do território como centrais, algumas vezes relacionando-os ao poder ou ao espaço rural; e apenas um programa de pós-graduação em história indica em seu projeto uma área de concentração diretamente ligada

37 GONÇALVES, Adilson José. A cidade como objeto do conhecimento. Museu Iconográfico da Saúde de São Paulo - artigos. Disponível em: < http://www.misp.pucsp.br/museu/artigos_02.html>. Acesso em: 01/11/2008.

38 Nas diretrizes da Capes para a definição dos programas de pós-graduação, o nome do programa e a área de concentração devem delimitar o campo de atuação e a formação oferecida pelos cursos; recomenda-se que a área expresse a vocação inicial ou histórica do programa e os contornos gerais de sua especialidade na produção do conhecimento e na formação esperada. 
à cidade - "política, memória e cidade" 39 . Expressariam, no conjunto, uma ausência da tematização da cidade? Difícil afirmar, quando ainda se tem uma apreensão apenas panorâmica da cidade no amplo repertório das áreas de pesquisa, quando ainda é a distância que nos dá o enquadramento - mais uma vez tomando como inspiração os "objetos perdidos" de Benjamin. A prevalência da história social pode também ser investigada e apreendida a partir das dinâmicas e circunstâncias da criação dos primeiros cursos de mestrado e doutorado na década de 1970, e dos desdobramentos da configuração desses paradigmas conceituais - sem dúvida um campo de investigação importante e instigante, mas pouco promissor para as questões aqui levantadas. Ademais, uma visão panorâmica sobre os mestrados e doutorados na área de história não deixa dúvidas: a cidade não está/esteve no foco dos debates - é o que nos diz o enquadramento à distância. Talvez tenhamos aqui um segundo indício dos desvios, mesmo que o alcance dessa mirada ainda o deixe pouco claro, esperando ser desvelado.

\section{ENTRE QUESTÕES SOCIAIS E CULTURAIS}

Vitalidade e opacidade do urbano. Para passar desse quadro geral à minúcia daquilo que cada grupo de pesquisadores ou cada programa produz teríamos que atravessar uma pesquisa exaustiva entre teses e publicações que ultrapassaria em muito nossos objetivos. Escolhemos outro percurso, buscamos nova orientação na proximidade. Acompanhamos a produção da Revista Brasileira de História, publicação da área acadêmica de história diretamente ligada à Associação Nacional de História-ANPUH, que editou 55 números entre 1981 e meados de $2008^{40}$. A partir de seu quinto

39 "Política, memória e cidade" é uma das quatro áreas de concentração da pós-graduação em História da Unicamp. Esta área é originária da antiga linha de pesquisa Cultura e Cidades, iniciada na década de 1980 na Unicamp, como já mencionado anteriormente; atualmente é uma área de concentração - ao lado de história social, história cultural e história da arte - e se organiza em torno de duas linhas de pesquisa: "Jogos do político: conceitos, representações e memória"; "Cultura, cidade e patrimônio".

40 Órgão oficial da ANPUH, figura entre os periódicos de expressiva relevância para a produção acadêmica dos historiadores no país, além de ter ampla circulação. Certamente outras publicações poderiam referenciar este levantamento, tais como: Varia História, da UFMG, Tempo, da UFF, História, da Unesp, Estudos Históricos, da FGV, entre outras, mas nenhuma poderia alcançar a especificidade da Brasileira de História por sua abrangência definida, a priori, por sua condição de órgão oficial de uma associação de caráter nacional. 
número, em 1983, cada edição do periódico foi organizada em torno de um dossiê temático. Somente três deles focalizaram temas urbanos ou ligados diretamente à cidade: recentemente, em 2007 (dossiê: Cidades, volume 27, n. 53), em 2003 (dossiê: Experiências Urbanas, volume 23, n. 46) e em 1984-1985 (dossiê: Cultura e Cidades, volume 5, n. 8/9).

O primeiro dossiê da década de 1980 nos parece exemplar para o entendimento de como se estabeleceu aos poucos - e se apresenta atualmente - o tema urbano nos estudos de história no Brasil. Não que o próprio dossiê buscasse, por meio de seus editores ou autores, traçar de alguma forma uma diretriz para a pesquisa sobre cidades, ou que tivesse sido determinante de escolhas posteriores do campo da historiografia. Visto a posteriori, o número 8/9 da Revista Brasileira de História parece figurar como prenúncio de um quadro que se atualizaria mais tarde, quase provocativamente. Vejamos os temas dos artigos: cotidiano, violência e vigilância urbana (análise feita por Storch); sensibilidade e razão na apreensão das transformações nas metrópoles, sob um ponto de vista de matriz política e outro, poética (Bresciani; Sevcenko); trabalho e tensões sociais na cidade (Chalhoub, Ribeiro e Esteves); mobilizações políticas e cidadania (Carvalho); modernização e intervenções urbanas (Pechman e Fritsch); patrimônio cultural e memória (Menezes) ${ }^{41}$. Ao ensaiarmos uma aproximação entre esse conjunto de temas, todos ligados à cidade, e os assuntos abordados nas pesquisas recentes sobre o urbano na historiografia - por exemplo, tomando-se aqueles descritos no Diretório do $\mathrm{CNPq}$ - é possível, grosso modo, percebermos algumas permanências. Movimentos sociais, política, violência, trabalho, modernização, cidadania, memória, cultura e sensibilidades urbanas: cada um desses conceitos estudados nos artigos do primeiro dossiê figura em nosso levantamento das pesquisas recentes. Porém, adotam outras perspectivas de análise e não exploram a cidade com as mesmas ênfases ou preocupações, seguramente. Se

41 Os seguintes textos compõem este primeiro dossiê Cultura e Cidades: STORCH, R. D. O policiamento do cotidiano na cidade vitoriana; BRESCIANI, M. S. M. Metrópoles: as faces do monstro urbano (as cidades no século XIX); SEVCENKO, N. Perfis urbanos terríveis em Edgar Allan Poe; CHALHOUB, S.; RIBEIRO, G.; ESTEVES, M. A. Trabalho escravo e trabalho livre na cidade do Rio: vivência de libertos, "galegos" e mulheres pobres; CARVALHO, J. M. O Rio de Janeiro e a República; PECHMAN, R; FRITSCH, L. A reforma urbana e seu avesso: algumas considerações a propósito da modernização do Distrito Federal na virada do século; MENEZES, U. T. B.O museu na cidade/a cidade no museu: para uma abordagem histórica dos museus na cidade. 
acrescentássemos estudos a partir da cultura visual, como a fotografia e o cinema, e sobre a relação entre cidadania/identidades e memória, teríamos nesse dossiê um surpreendente ensaio prévio do desenvolvimento posterior das pesquisas sobre cidades no campo da história ${ }^{42}$. Todavia, algo chama a atenção nesse quadro temático: a problematização da cidade, pela abordagem histórica, nos primeiros delineamentos expressos no dossiê (e de certa maneira coincidentes com os estudos então em pauta), não parecia alimentar separações ou hierarquias entre temas culturais e urbanos, mas sim valer-se dos conceitos e elementos advindos de outros repertórios de pesquisa para se pensar historicamente a cidade. O aporte teórico mobilizado, por exemplo, para as pesquisas sobre o pensamento político e sobre a experiência (e expressão) estética são atualizados a propósito dos temas urbanos. A discussão sobre as sensibilidades urbanas no dossiê aponta nessa direção quando problematiza as dimensões estéticas das metrópoles acentuando-lhes a abrangência política e histórica. Tematiza-se não apenas a experiência impactante da vida nas grandes cidades desde as primeiras décadas do XIX, tomada a partir de suas diversas formas de expressão - poética, científica, política, técnica, literária -, mas analisa-se detidamente as dimensões políticas dessa experiência, dessas expressões ${ }^{43}$.

Mais de duas décadas depois, a despeito da clareza e unicidade do título - Cidades -, o dossiê da Revista Brasileira de História de 2007 seria mais preciso se tivesse reeditado o título de 1985. O assunto dominante entre os doze artigos é a cultura, as interpretações, narrativas e leituras que se faz do urbano: cidade como sentimento; interpretações e seduções da modernidade; narrativas do cinema, da crônica, da fotografia, das revistas ilustradas, da música sobre a cidade ou a partir dela; representações do progresso; polifonia dos territórios ${ }^{44}$. Talvez possa figurar à margem dessa tônica o artigo sobre o sanitarismo e a urbanização, dedicado a explorar os caminhos do saber médico nas relações entre saúde, doença e urbanização da

42 As pesquisas sobre memória e identidade, aliás, abriram uma importante área de estudos e atuação na história, seja considerando-se a significativa atuação de historiadores nas políticas de patrimônio, seja nas discussões sobre o papel social da memória, inclusive no âmbito de políticas públicas. Sobre essa abertura é exemplar o trabalho já citado: $O$ direito à memória.

$43 \mathrm{Em}$ especial os textos de Sevcenko e Bresciani, que aprofundam as análises sobre a abrangência desses impactos nas metrópoles.

44 Todos os artigos do v. 27, n. 53, jan./jun. 2007, estão disponíveis no portal Scielo, no endereço: <http://www.scielo.br/scielo.php?script=sci_issuetoc\&pid=0102-018820070001\&lng=en\& nrm=isso $>$. Acesso em: 19/10/2008. 
cidade de São Paulo ${ }^{45}$. Contudo, no conjunto, também ele acaba envolvido pelas questões culturais que permeiam todo o volume, desde o panorâmico ensaio que inicia o dossiê, sobre os percursos das abordagens culturais da cidade $^{46}$. Pesavento faz nessa abertura não um artigo, mas um passeio pelos temas urbanos e pelos rastros - indícios, sinais, documentos, registros - com os quais lida o historiador voltado ao estudo da cidade. À primeira vista trata-se de uma tentativa de balanço dessa historiografia sobre o urbano, mas no percurso mostra-se como a defesa de uma abordagem específica do tema. O ponto de partida é o fascínio da cidade, em que se atualiza como central a questão da sensibilidade, abordada ao lado das formas de representação do urbano. Sintetiza uma trajetória, a nosso ver simplificadora, das análises históricas sobre a cidade: inicialmente, as chamadas histórias de cidades, como narrativas evolutivas desde as origens; nas décadas de 1960 a 80 , a história econômica e social, sobretudo de matriz teórica marxista, que apreende a cidade como lugar de engendramento das forças capitalistas e de tensões sociais e políticas; por fim, na década de 1990, a história cultural, que "veio proporcionar uma nova abordagem do fenômeno urbano". A partir da emergência desses estudos culturais "a cidade não é mais considerada como um locus privilegiado, seja da produção, seja da ação de novos atores sociais, mas, sobretudo, como um problema e um objeto de reflexão ${ }^{47}$." Segundo afirma, a história cultural urbana busca a "cidade que é fruto do pensamento, como uma cidade sensível e uma cidade pensada", capaz de se apresentar mais efetivamente à percepção dos habitantes e passantes do que a materialidade ou o "tecido social concreto". A autora percorre então os registros e documentos dessa cidade sensível: escritas sobre a cidade, sobretudo do campo literário; discursos sobre o urbano, técnicos e afins; registros da oralidade e da memória; diversos suportes da representação da urbe: imagens mentais e pensamento, iconografia (cartografia, gravuras, pinturas, fotografia), cinema, teatro. É a cidade como projeção do imaginário, nos diz, sempre pensada através do presente.

45 SILVA, Márcia Regina B. da. O processo de urbanização paulista: a medicina e o crescimento da cidade moderna. Revista Brasileira de História. São Paulo: ANPUH, v. 27, n. 53, p. 243-266, jan./jun. 2007.

46 PESAVENTO, Sandra Jatahy. Abertura - Cidades visíveis, cidades invisíveis, cidades imaginadas. Revista Brasileira de História. São Paulo: ANPUH, v. 27, n. 53, p. 11-23, jan./jun. 2007.

47 Ibid., p. 12-14. 
É este precisamente o ponto de inflexão do percurso crítico aqui proposto: tomando-se como possível o quadro delineado pela autora e com isso admitindo-se como ponto de chegada para os estudos sobre a cidade uma adesão às perspectivas da história cultural, seria importante indagar sobre possíveis relações dessa avaliação e dessa escolha com as questões atualmente em discussão nas abordagens historiográficas. Sem adentrar as discussões acerca do suposto enfraquecimento de paradigmas explicativos no campo das ciências sociais nas últimas décadas, bem como os intensos debates em torno do estatuto epistemológico das humanidades e da história - mas também sem ignorar inteiramente os prováveis efeitos, imaginados ou não, dessas discussões - entendemos ser importante indagar sobre a presumida prevalência e refletir sobre esse elogio dos estudos culturais em relação ao urbano. Diante de um provável estado de indecisão do campo disciplinar, seriam eles refúgios do saber histórico ${ }^{48}$ ? Perguntamos ainda: esse refúgio poderia tomar forma no relativo afastamento das perspectivas da história cultural em relação aos paradigmas sociais e políticos? A partir de seus desdobramentos, seria responsável, por exemplo, por conduzi-la ao distanciamento de uma história das ideias e induzir à micro-história, o estímulo à história cultural, à valorização dos traços informais, cotidianos e/ou casuais da cultura? Ao depositar expressiva força nos estudos sobre imaginário, sensibilidades, ou mesmo ideologias, estaria a chamada história cultural urbana negligenciando mediações entre as condições objetivas e as narrativas e representações desse vivido? Certamente essas questões merecem uma reflexão mais detida, teórica, histórica ${ }^{49}$. É preciso considerar ainda uma vez a importância dada à sensibilidade nos estudos sobre a cidade

48 Ao tecer reflexões acerca do estatuto das abordagens culturais na historiografia contemporânea, especialmente a brasileira, Vainfas acompanha os desdobramentos das críticas às chamadas histórias das mentalidades, indicando aproximações e desdobramentos relacionados aos estudos culturais. A partir desse percurso e dos posicionamentos de Chartier no estudo usualmente tomado como referencial para se entender as abordagens da história cultural, acompanhamos as avaliações críticas de ambos acerca da propalada "crise" das humanidades e suas relações com os estudos culturais. VAINFAS, Ronaldo. História das mentalidades e história cultural. In: CARDOSO, C. F.; VAINFAS, R. (Orgs.). Op. cit., p. 127-162. CHARTIER, Roger. O mundo como representação. Estudos Avançados, v. 11, n. 5, p. 173-191, 1991.

49 Raminelli, em análise da história urbana já citada, lança uma dúvida sobre os estudos culturais na historiografia sobre cidades ao concluir que parte desses estudos "está mais preocupada em seguir os caminhos de Benjamin e Marshall Berman do que em fazer pesquisa histórica". RAMINELLI, R. Op. cit., p. 202. Sarlo, por sua vez, insere suas análises sobre os estudos culturais em uma crítica enfática a usos superficiais de trabalhos acadêmicos e exemplifica em Bakthin, Foucault e Benjamin "a expansão difusa mas ampla de certas modas teóricas", que repercutem, segundo afirma, no aumento de estudos sobre cidades. SARLO, Beatriz. Paisagens imaginárias: intelectuais, arte e meios de comunicação. Coleção Ensaios Latino-americanos. 2. ed. São Paulo: Edusp, 2005, p. 97-107. 
- por vezes expressa de modo claro e direto: a cidade é sensibilidade, a cidade é um fato cultural - e o extenso percurso de análise das mudanças nas sensibilidades urbanas contemporâneas - desde a ampla produção literária do século XIX, passando pelos estudos de Simmel e Benjamin sobre os efeitos da experiência da modernidade. Ao considerar essa dimensão, tornase muito limitado relevarmos exclusivamente o papel do pensamento na configuração da cidade ${ }^{50}$.

$\mathrm{Na}$ relação entre pensamento e cidade, é preciso pontuar a importância da sensibilidade culta, expressa na extensa produção intelectual no século XIX, como possibilidade de se apreender o novo, conhecendoo, controlando-o, deixando-se alcançar por ele. Sevcenko e Bresciani exploraram essa sensibilidade em muitos de seus desdobramentos, nos estudos publicados no já citado dossiê da Revista Brasileira de História de 1985. Nas diversas percepções até mesmo contraditórias da cidade foram produzidas imagens de grande intensidade instigadas pelo surgimento das grandes metrópoles, imagens que não só apreendiam aquilo que foi entendido por muitos como uma nova era como também definiam novas abordagens da sociedade urbana e sua materialidade. Sevcenko acompanha nas imagens literárias de Edgar Allan Poe (1809-1849) o enquadramento da cidade moderna sob emblemas aterradores - da solidão, da doença, da morte - gerados diante dos estímulos da experiência e observação do poeta na metrópole. Não que a cidade, em si, fosse responsável por esse ineditismo, mas apresentava-se como um observatório privilegiado, um ponto estratégico para se compreender as transformações em curso. Nas imagens produzidas no período, a cidade figura ao lado das máquinas (com seu poder transformador e promissor) e da multidão (experiência desconcertante e tão cara às expressões literárias) como "trinômio do progresso", paradigmas da nova sensibilidade, a um só tempo fascinante e terrível, nos diz Bresciani ${ }^{51}$. O entrelaçamento entre as duas forças

50 Raminelli apresenta um percurso da questão sensível na cidade e situa os pensadores Georg Simmel e Walter Benjamin em relação aos estudos urbanos. Sobre literatura e mudanças nas sensibilidades urbanas, além dos textos já citados, do dossiê: Cultura e Cidades da Revista Brasileira de História, de Sevcenko e de Bresciani, esta mesma autora explorou a questão da literatura no XIX em: Século XIX: a elaboração de um mito literário. História: questões \& debates, n. 13, p. 209-244, 1986. Outras importantes aproximações entre literatura e história, sob o prisma do urbano e seus impactos, têm sido feitas na historiografia com significativo êxito. Willi Bolle, por exemplo, explora com maestria a questão em: Fisiognomia da metrópole moderna: representações da história em Walter Benjamin. 2. ed. São Paulo: EDUSP, 2000.

51 BRESCIANI, S. Op. cit., 1985. 
transformadoras na avaliação de muitos contemporâneos - a máquina e a revolução, em especial a Revolução Francesa e a imagem do poder destruidor das multidões nas ruas - modificou também as concepções sobre a sociedade no período, sobretudo o pensamento sobre a o homem "desnaturado" pela máquina e sobre a pobreza na cidade.

A percepção de coisas que parecem inéditas, assustadoras, poderosas em sua força, infinitas ou com seus limites velados, portentosas, enfim, compõe essa nova sensibilidade no século XIX. A força de atos inaugurais, com seu caráter revelador de coisas antes submersas, e com seu poder transformador, ficou para sempre marcada na grandeza da imagem construída pelos homens que presenciaram a imposição da máquina e se chocaram com a revelação pública das necessidades e expectativas dos homens pobres ${ }^{52}$.

Mas a perplexidade perante as concentrações humanas e o operariado não se encerra nas novas percepções. Buscava-se compreender esse "monstro urbano" e seus perigos, para poder corrigi-lo. O fascínio e o medo orientaram uma atitude exploratória concentrada nos levantamentos sobre o modo de vida dos homens pobres trabalhadores ou vagabundos e seu habitat, quase sempre desconhecido dos observadores (médicos, políticos, reformadores sociais etc.). Conceitos, abordagens e atitudes perante a cidade são forjados nesse contexto, e o estudo histórico a propósito desse momento crucial para a configuração das concepções contemporâneas do urbano é aqui entendido como indispensável à formação desse campo de pesquisas, que a inclui mas não se resume à sensibilidade.

\section{PAISAGENS MODERNAS OU O AVESSO DO AVESSO}

Modernização, reformas e intervenções urbanas, imagens do progresso, ou simplesmente urbanização: são temas reiteradamente presentes nos estudos históricos sobre cidades, sobretudo quando focalizam as cidades 
após a segunda metade do século XIX no Brasil, com destaque para os grandes centros e aqueles que passaram por amplas transformações ${ }^{53}$. As pesquisas sobre as bases materiais dos processos de modernização jamais deixaram de ter seu lugar nos estudos da história, porém os deslocamentos constantes para as percepções e narrativas sobre essa transformação têm alterado seu relevo. Inicialmente abordada como desdobramento de processos econômicos e de adensamento populacional, a modernização tem figurado predominantemente como uma experiência sensível - e sem dúvida ela o é - e como uma nova forma de vivenciar a vida urbana muitas vezes sem que se problematize o alcance dessa nova vivência e experiência. Apresentar a cidade sob a égide da modernização sem discutir tenazmente, por exemplo, as dimensões políticas capazes de colocar pessoas e projetos em apoio das representações estéticas relativas a essa nova experiência urbana põe em risco a compreensão da cidade como fenômeno urbano. Ela pode ser reduzida a apenas um lugar saturado de significações acumuladas. Modernização no âmbito da história urbana pode sugerir a reposição de imagens sempre positivas, aliadas aos valores do progresso, impressas em certa linearidade capaz de destituir o lugar da reflexão histórica na investigação desses processos.

Vejamos algumas dessas questões em estudos sobre cidades na contemporaneidade, sobretudo em análises que mantêm contato com a questão da modernização a partir do final do século XIX. O predomínio de exemplos sobre São Paulo é apenas indicativo dos percursos pessoais de pesquisa e do volume da produção bibliográfica sobre a questão urbana na capital paulista ${ }^{54}$. Três quadros podem ser delineados nesses estudos: um apóia o entendimento sobre a modernização em elementos exteriores a ela; outro repõe os valores de época como chaves de análise; um último retoma a ideia da cidade como um cenário de tensões ${ }^{55}$.

53 Um levantamento bibliográfico feito na década de 1990 deixa indícios da importância, então, dos estudos sobre urbanização e processos de transformações nas cidades, sendo a modernização atrelada a esses processos. IOKOI, Zilda Márcia Gricoli (Org.). Bibliografia comentada: industrialização, urbanização e migrações, São Paulo, séculos XIX e XX. São Paulo: DH-USP, 1995; outra referência é o Banco de Dados URBANDATA: originalmente publicado como livro, hoje é um banco de dados sobre o Brasil urbano, com base digital. Disponível em: <http://urbandata.iuperj.br>. Acesso em: 17/10/2008.

54 Como também ocorre na primeira parte desta exposição, sobre a história na produção dos arquitetos.

55 Os três quadros aqui apresentados foram indicados, de modo mais sintético, em CERASOLI, J. F. Op. cit., 2004, p. 312-315. 
Primeiro quadro: modernização sem mudança. Uma síntese de determinadas matrizes de análise com grande repercussão na historiografia sobre cidades pode ser acompanhada no ensaio elaborado na década de 1970 por Viotti da Costa sobre o processo de urbanização brasileiro no século XIX. Apresenta um esquema de análise baseado em aspectos de caráter estrutural, de matriz marxista, determinantes das transformações na sociedade ao longo do XIX: base econômica agrário-exportadora, sistema político paternalista e clientelista, marginalização das maiorias, excluídas ou alienadas em relação às variáveis do processo. Essa estrutura se repetiria nas cidades, a partir da década de 1850 , com a introdução de algumas modificações, como o incremento da economia cafeeira, a expansão da rede ferroviária e a abolição da escravatura em 1888. A autora indica a permanência de "valores aristocráticos" e determinações econômicas no processo de urbanização no período, que resultaria, em última instância, em modernização sem mudança. Em síntese:

[...] a natureza do processo de desenvolvimento, preservando intactas as estruturas fundamentais da economia brasileira durante o século XIX seria responsável pela sobrevivência de estruturas de dominação, valores e formas de comportamento compatíveis com a sociedade tradicional ${ }^{56}$.

Interpretações com abordagens semelhantes deixam larga herança na historiografia, obliterando a compreensão das dinâmicas e contradições existentes no processo. São visões fortemente marcadas por esquemas explicativos estruturais e, mesmo quando anunciam a superação de tais esquemas, atualizam-nos e tornam-se significativamente recorrentes na bibliografia sobre urbanização, presentes sobretudo ao se vincular as renovações urbanas a "valores burgueses", ou ainda ao se reduzir a cidade a um projeto estratégico das elites políticas. O texto de Marins presente na difundida História da Vida Privada no Brasil constitui exemplo de adesão a esse pressuposto reelaborado na ideia de vizinhança. Ao analisar a construção de novos espaços na capital paulista da virada do século 
XIX-XX, estreitamente ligados à ideia de "civilização", forjou-se em São Paulo, segundo ele, uma mancha contínua de vizinhanças homogêneas nos "novos bairros elegantes, adequados aos preceitos sanitários, plásticos e comportamentais gerados no cotidiano burguês das cidades européias ${ }^{57}$." As dinâmicas plurais ligadas a processos complexos de distinção e produção de significados - sociais, estéticos, políticos - aparecem, assim, envoltas por valores exteriores e anteriores a eles. Estruturam-se as explicações sobre as escolhas e as formas adotadas (perfis arquitetônicos das edificações, dimensões e distribuição de ruas, quadras, recuos, etc.) nas vizinhanças seletas da capital em atributos diretos desses fatores externos, como se prescindissem das situações históricas estudadas e prescindissem da cidade para serem compreendidas como escolhas. O entendimento das estruturas econômico-sociais, nesse quadro, parece dispensar o entendimento da cidade.

Explicações previamente concebidas também fomentam a difusão de interpretações semelhantes em estudos voltados à história da arquitetura, largamente apoiados na historiografia. Retomamos pontualmente este aspecto já explorado na primeira parte desta apresentação no intuito de acrescentar-lhe a dimensão da exterioridade da explicação, agora inserida nas análises dos historiadores. Estudos recentes, como o de Eudes Campos, emolduram uma vasta pesquisa sobre a arquitetura paulista imperial - sobre escolhas técnicas e estéticas, relações políticas e simbólicas - nos "projetos da burguesia" emergente, enunciado definido já na introdução como matriz interpretativa. No caso da capital paulista, em particular, o entrecruzamento das análises estruturais com os discursos de "civilização" identificados às elites resulta ainda em outra interpretação, igualmente fértil na bibliografia: contrasta a presumida vida pacata da cidade no século XVIII com a emergência da metrópole cosmopolita no século XIX. Resultam ocultas também, desse modo, as fissuras e a pluralidade dos processos históricos - "São Paulo chegava à República recuperando-se do marasmo que estendera o aspecto setecentista até meados da década de 1870", afirma Marins. Entre as poucas exceções, vale ressaltar o estudo de Montóia sobre a cidade

57 MARINS, Paulo César Garcez. Habitação e vizinhança: limites da privacidade no surgimento das metrópoles brasileiras. In: NOVAIS, Fernando A. (Coord.); SEVCENKO, Nicolau (Org.). História da vida privada no Brasil, Vol. 3 - República: da Bélle Époque à Era do Rádio. São Paulo: Companhia das Letras, 1998, p. 131-214. 
de São Paulo por abrir brechas nesse paradigma interpretativo e fornecer elementos interessantes para se relativizar esse sempre repetido marasmo da vida paulistana oitocentista, atribuindo sentido político às oposições e conflitos, sintetizados na ideia de sombra e luz na cidade $^{58}$.

Segundo quadro: modernização sem tensões. A reiterada afirmação do domínio das elites políticas e econômicas nos processos de modernização traz outros desdobramentos no campo da história das cidades. Por caminhos diversos alguns estudos acabam por apostar na harmonia dos supostos "valores das elites", como se identificassem a predominância inquestionável de um projeto hegemônico excludente, por um lado, e reafirmassem a necessidade e/ou importância das reformas e transformações, sem observarlhes algum conteúdo político e ideológico, por outro. Reforçam mais uma vez certo paradigma progressista de interpretação, filiado à apreensão dos processos modernizadores como supostamente lineares, sem questionarlhes a procedência ou outros possíveis significados. Estudos voltados a aspectos culturais são particularmente profícuos nesse sentido, pois parecem incorporar com maior naturalidade matrizes de análises estruturais ou suas decorrências, ao repetir como pressuposto de seus estudos o progresso "em ritmo acelerado". Em estudo da Belle Époque paulistana baseado nas relações e atividades culturais de Freitas Valle, Camargos apóia-se em esquema explicativo constantemente retomado que justifica o progresso da capital pelo rompimento das elites com a tradição rural e o passado "atrasado", e adesão ao cosmopolitismo e à "civilização". Afirma: "sob o influxo comercial da concentração de recursos financeiros e da assimilação dos novos preceitos e valores burgueses europeus, a capital viu surgir palacetes, avenidas, desenhadas para receber os automóveis e diversos tipos de indústrias ${ }^{59}$." O apoio em expressões culturais das chamadas elites letradas, nesse caso, torna ainda mais importante o cuidado com as explicações prévias, visto que os próprios registros e documentos

58 MONTÓIA, Ana Edite Ribeiro, Op. cit.; CAMPOS, Eudes. Arquitetura Paulista sob o Império: aspectos da formação da cultura burguesa em São Paulo. Tese (Doutorado em Arquitetura) - FAUUSP, São Paulo, 1997, 4 vol. (especificamente a introdução, no $1 .^{\circ}$ vol.), entre outros.

59 CAMARGOS, Márcia. Villa Kyrial: crônica da Belle Époque paulistana. São Paulo: Senac, 2000, p. 32. Nesse mesmo sentido, também Naclério Homem, analisando detidamente as formas de morar e construir dos palacetes em período semelhante, declara: "nasceu a 'capital' dos fazendeiros de café". HOMEM, Maria Cecília Naclério. O Palacete paulistano e outras formas de morar da elite cafeeira, 1867-1918. São Paulo: Martins Fontes, 1996. 
podem induzir a leituras que sobrepõem as noções e projetos da época às reflexões históricas. Mesmo estudos de fôlego, ancorados em ampla documentação, são sujeitos a essas armadilhas quando referenciados a priori em interpretações como essa, do necessário rompimento com a tradição rural como determinante da adesão a novos padrões culturais, quase sempre entendidos como importados ${ }^{60}$.

Terceiro quadro: modernização pelo avesso. É significativo pontuar a preponderância de interpretações que buscam relativizar os paradigmas anteriores sob os enfoques da chamada história social, entre análises votadas aos estudos de espaços ou grupos considerados excluídos. São interpretações francamente atentas às contradições e às discrepâncias identificadas nos processos de transformação, e destacadamente tomadas pela visão das maiorias marginalizadas. $\mathrm{O}$ instigante estudo de Wissenbach, outro capítulo da História da Vida Privada, acrescenta elementos bastante interessantes para se pensar as contradições do processo de transformação da capital paulista, ao acompanhar as experiências de constituição da liberdade de ex-escravos:

Obliterar formas sociais e de convívio dissonantes ao projeto modernizador, negar a diversidade da nação por meio de um discurso que homogeneizava, foram intenções claras dos registros históricos produzidos no período [final do século XIX] que vimos abordando ${ }^{61}$.

Sem dúvida acrescentam elementos de grande relevância para a compreensão da pluralidade e dissonâncias presentes nos processos históricos estudados, mas ainda assim no quadro exposto parece não haver ruídos ou conflitos nas definições dos projetos "hegemônicos e lineares" de

60 A despeito de significativas contribuições para a pesquisa sobre a intelectualidade em suas variadas formas de expressão - na literatura, no jornalismo e nas artes, por exemplo - o instigante estudo de Sevcenko sobre os anos 1920 em São Paulo deixa entrever esse predomínio cultural das elites, tão vorazes na atualização de seus "cosmopolitismos" que teriam deixado a própria metrópole extasiada, sem ação diante da agitação febril. SEVCENKO, Nicolau. Orfeu extático na metrópole: São Paulo, sociedade e cultura nos frementes anos 20. São Paulo: Companhia das Letras, 1992.

61 WISSENBACH, Maria Cristina Cortez. Da escravidão à liberdade: dimensões de uma privacidade possível. In: NOVAIS, Fernando A. (Coord.); SEVCENKO, Nicolau (Org.). Op cit., p. 49130 . 
modernização e "civilização" que permanecem intactos ${ }^{62}$. As perspectivas analíticas configuradas com essa chave de leitura - ou seja, direcionadas para a busca dos enfrentamentos nas forças sociais - podem permitir uma investigação sobre relações de poder mais complexas e contraditórias. Todavia, quando priorizam o confronto de classes e a dominação política relativizam até mesmo a complexidade do painel tenso que descrevem, enquadrado sob dualidades (polos opostos) constantemente retomadas. Também a cidade, nesse caso, figura como cenário ou - para retomar a metáfora inicial - como paisagem do social ${ }^{63}$.

Os exemplos selecionados não esgotam ou não pretendem dar conta de uma revisão crítica da bibliografia sobre cidades ou sobre a capital paulista do ponto de vista historiográfico; são somente indícios da paisagem que buscamos mapear. Nela, temos a impressão de apenas entrever a cidade que se supunha no foco de vários desses estudos. Vemos nessa paisagem um novo e decisivo desvio dos estudos da chamada história urbana. A cidade, mais uma vez, apresenta-se de forma oblíqua. A história apreende a cidade como cenário, panorama, ou depositária de uma trajetória histórica; dificilmente é focalizada a partir da multiplicidade de forças e tramas que a constitui. Responderia a urbe apenas à simples questão: onde transcorre essa trama? Onde "aconteceu"? Poderíamos dizer que na historiografia a cidade tem, acima de tudo, figurado como resolução da categoria espaço, na reiterada intersecção tempo-espaço, tão cara ao campo da história?

Se levarmos adiante o levantamento ou o mapa dos desvios aqui sugeridos provavelmente a cidade se apresentaria esmaecida no foco dos estudos históricos. No inventário dos temas políticos - identidades,

62 Outros estudos norteados pela busca das fissuras do processo: MUNHOZ, Sidnei. A cidade ao avesso: desordem e progresso em São Paulo no limiar do século XX. Tese (Doutorado em História Econômica) - FFLCH-USP, São Paulo, 1997; SANTOS, Carlos José Ferreira dos. Nem tudo era italiano: São Paulo e pobreza (1890-1915). São Paulo: Annablume-Fapesp, 1998, entre outros.

63 Estudar os saberes e práticas ligados à doença na cidade entre a segunda metade do século XIX e as primeiras décadas do XX não deixa de ser um estudo sobre a cidade, sobretudo se considerarmos o papel decisivo dos preceitos higiênicos e sanitários na formação dos campos conceituais que fundamentam as intervenções no urbano. Insere-se nesse caso, por exemplo, o estudo de Chalhoub sobre o Rio de Janeiro, quando se volta à pesquisa sobre os cortiços e as políticas de saúde na cidade. $\mathrm{O}$ autor aborda os chamados mecanismos de dominação a partir da definição de um quadro complexo e não consensual em relação à higiene envolvendo vários segmentos da sociedade, mas ao priorizar o desvelamento da luta de classes e do "reordenamento estrutural nas políticas de dominação", termina por relativizar as dissonâncias e ambiguidades, dando relevo às supostas lutas hegemônicas. CHALHOUB, Sidney. Cidade febril: cortiços e epidemias na Corte Imperial. São Paulo: Companhia das Letras, 1996. 
cidadania, memória, cultura política, poder, ou mesmo território - a cidade que predomina se interpõe usualmente como palco das ações, como lugar das intervenções, como espaço para o poder, por exemplo. Algo similar se repete quando a ênfase recai nos aspectos sociais - sociabilidades, movimentos sociais, relações sociais e de trabalho. Paisagens sociais. E mesmo quando se parte da definição de escalas de análise - história local e regional, muitas vezes entendida como uma história urbana - corre-se o risco de um novo desvio, visto que mais uma vez a narrativa política ou a encenação das relações sociais pode adquirir maior relevo. Mesmo a festejada história cultural, ao priorizar essencialmente a cidade como representação (até quando aborda as sensibilidades) em termos gerais, acaba por separar o urbano de sua materialidade, inclusive no âmbito das diferenças, divergências e disputas constituintes da cidade, simbólica e materialmente.

Quando herdeiras de paradigmas explicativos previamente formulados, as abordagens tornam-se facilmente reféns de interpretações francamente comprometidas com noções e aportes ideológicos pouco favoráveis ao entendimento dos processos históricos que se propõem a estudar. No caso das pesquisas sobre processos de modernização o forte apelo à visualidade e à materialidade das transformações analisadas - expresso em referenciais arquitetônicos, artísticos, literários, ou na citação recorrente de exemplos de países europeus - favorece explicações que se tornaram senso comum, como a noção da importação e adaptação de planos, projetos e modelos e a inexistência de qualquer expressão de alguma possível "originalidade" ou, talvez de modo mais pertinente, a participação dos profissionais atuantes no Brasil na partilha de conhecimentos técnicos difundidos em congressos, exposições, artigos, livros, relatórios etc., de ampla circulação nos meios especializados. Sem discutir os processos históricos implicados nas escolhas de procedimentos urbanísticos e arquitetônicos, sem buscar compreender o caráter universalizante, internacional até, que dita muitos desses preceitos - sobretudo aqueles relativos padrões técnicos, estéticos e de comportamento - a história urbana pode figurar meramente como reposição reiterada de paradigmas explicativos exteriores à cidade ${ }^{64}$. A permanência e repetição

64 Acreditamos ser importante mais uma vez reiterar a crítica que tem sido, paulatinamente, apresentada a respeito de uma interpretação nascida nas análises literárias e que tem alcançado ampla repercussão nas humanidades, referente às "idéias fora do lugar". No campo da história urbana, essa noção 
desses paradigmas resultantes em avaliações que insistem na ideia de adaptação, aclimatação e inadequação de ideias e projetos supostamente estranhos ao país acaba, portanto, por recolocar um desvio nas interpretações sobre a cidade. Entendida como parte desse limitador processo de importações, a narrativa sobre o processo de modernização de uma cidade poderia então ser entendida como modelar para qualquer outra. Se os modelos culturais se repetem, que significado teria o estudo da história urbana? Apreendida como paisagem ou cenário de lutas sociais, políticas e ou simbólicas, cuja materialidade praticamente se resume a territórios supostamente marcados pela experiência social ou narrados nos mais variados suportes, a cidade parece escapar à história.

\section{Desafios, para além dos desvios}

É possível uma abordagem histórica da cidade que supere esses desvios? Poderia a história privar a cidade de sua materialidade e conferir primazia exclusiva às tensões sociais ou à construção de significados e representações? Estaria a história da cidade apta a dar conta das muitas dimensões e lógicas que permeiam a configuração do urbano e os modos de se pensar e intervir na urbe? Longe de esgotar essas questões, que remetem inclusive a outros campos disciplinares e perspectivas à margem desta discussão, buscamos expor um quadro amplo de escolhas, possibilidades e dilemas no qual elas se inserem. Todas plausíveis na abrangência das relações entre cidade e história, essas questões remetem forçosamente à materialidade, aos modos de se apreender a dimensão tangível da cidade. Sem dúvida o fenômeno urbano é um fenômeno cultural, mas é fundamental para compreendê-lo que se considere a cidade em sua materialidade também como produção social. Não queremos retomar qualquer aparente dicotomia, mas avançar em relação a possíveis divisões.

teve ampla aceitação, adaptada em "referências em que se procede ao recorte obtido de rotular a prática arquitetônica e urbanística", por exemplo, "como importação inadequada ou transferência empobrecida de idéias e projetos idealizados em solo europeu para uma 'realidade' outra.” BRESCIANI, Maria Stella Martins. Imagens de São Paulo: estética e cidadania. In: FERREIRA, Antônio; LUCA, Tania Regina de; IOKOI, Zilda Grícoli (Orgs.). Encontros com a História: percursos históricos e historiográficos de São Paulo. São Paulo: Ed. UNESP, 1999, p. 11-45. 
Parecem-nos significativas para isso, entre outras possibilidades, algumas abordagens que têm sido feitas acerca de um elemento ao mesmo tempo palpável e intangível na cidade: a água. Na história da cidade, as presenças e os usos das águas relacionam-se a diferentes práticas, concepções, saberes, projetos ao longo do tempo. Sant'Anna, em minucioso estudo sobre as águas na cidade de São Paulo no século XIX, percorre seus diferentes usos passando da visibilidade à dissimulada e fundamental presença das águas na salubridade urbana ${ }^{65}$. Sensível à importância material das águas em múltiplas dimensões - desde a sociabilidade nos chafarizes até as intervenções técnicas no estabelecimento de redes de água e esgoto -, o estudo não se furta à discussão dos significados e dos embates que envolveram essa presença ${ }^{66}$. $\mathrm{O}$ espectro de assuntos e questões relativas à água na cidade é bastante abrangente e importante para se entender os objetivos desta análise. Amplas dimensões da cidade e seu conteúdo histórico se dão a conhecer por meio do estudo dos saberes especializados envolvidos na gestão das águas (medicina, engenharia civil, técnicas construtivas, cartografia, engenharia sanitária, urbanismo, direito) e das concepções de ordenamento urbano (espacial e moral, quando se pensa na ação disciplinar ligada a novos hábitos de higiene se estimulam ${ }^{67}$ ).

É impensável separar-se a materialidade e de outras dimensões do urbano ao se estudar as maneiras como se operam as ações de melhoramentos urbanos - para se usar uma terminologia da época - em suas imbricadas relações com os projetos políticos e as concepções estéticas que definem o espaço da cidade. Cada elemento definidor do tecido urbano - legislação, orientação dos arruamentos, implantação de lotes, regulamentação das edificações, padrões e materiais construtivos, estilos arquitetônicos, etc. - ultrapassa e contém sua dimensão tangível. De cada um é possível acompanhar sua densidade histórica e a confluência de saberes e projetos que o definem. Os sinais das sensibilidades contemporâneas que dialogam e se expõem em tensões na cidade não se esgotam nas expressões estéticas

65 SANT'ANNA, Denise Bernuzzi de. A cidade das águas: usos de rios, córregos, bicas e chafarizes em São Paulo (1822-1901). São Paulo: SENAC, 2007.

66 Outros trabalhos, como o de Cerasoli, já citado (2004), também abordaram a questão da presença das águas pela via das discussões em torno das obras públicas que viabilizaram a instalação de uma ampla infraestrutura de saneamento urbano na capital paulista no início do século XX.

67 Referimo-nos, mais uma vez, às importantes contribuições do estudo de Béguin nesse aspecto. BÉGUIN, F. Op. cit. 
nela presentes - literárias, arquitetônicas, urbanísticas - mas ampliam-se nas preocupações sanitárias e seus elos duradouros com as funções formadoras da cidade - dimensões moralizantes e/ou pedagógicas das ações sobre a cidade, até como resíduos da perplexidade que instiga o olhar sobre a cidade pelo menos desde o século XIX. Uma abordagem histórica da cidade que possa ansiar o alcance dessa complexa pluralidade de saberes e dimensões - planos simultâneos e sobrepostos numa mesma paisagem - deveria, pois, buscar apoio nos vários campos conceituais e disciplinares que a constituem. 